\title{
Innovative multifunctional hybrid photoelectrode design based on a ternary heterojunction with super-enhanced efficiency for artificial photosynthesis
}

Wayler S. dos Santos ${ }^{1}$, Éder J. Carmo ${ }^{1}$, Yanela Mendez-González ${ }^{2}$, Lucas L. Nascimento ${ }^{3}$ Antônio O. T. Patrocínio ${ }^{3}$, Ruyan Guo ${ }^{4}$, Amar S. Bhalla ${ }^{4}$, Jean-Claude M'Peko $^{5}$ \& José D. S. Guerra ${ }^{1 \bowtie}$

Electrochemical cells for direct conversion of solar energy to electricity (or hydrogen) are one of the most sustainable solutions to meet the increasing worldwide energy demands. In this report, a novel and highly-efficient ternary heterojunction-structured $\mathrm{Bi}_{4} \mathrm{O}_{7} / \mathrm{Bi}_{3.33}\left(\mathrm{VO}_{4}\right)_{2} \mathrm{O}_{2} / \mathrm{Bi}_{46} \mathrm{~V}_{8} \mathrm{O}_{89}$ photoelectrode is presented. It is demonstrated that the combination of an inversion layer, induced by holes (or electrons) at the interface of the semiconducting $\mathrm{Bi}_{3.33}\left(\mathrm{VO}_{4}\right)_{2} \mathrm{O}_{2}$ and $\mathrm{Bi}_{46} \mathrm{~V}_{8} \mathrm{O}_{89}$ components, and the rectifying contact between the $\mathrm{Bi}_{4} \mathrm{O}_{7}$ and $\mathrm{Bi}_{3.33}\left(\mathrm{VO}_{4}\right)_{2} \mathrm{O}_{2}$ phases acting afterward as a conventional $p-n$ junction, creates an adjustable virtual $p-n-p$ or $n-p-n$ junction due to self-polarization in the ion-conducting $\mathrm{Bi}_{46} \mathrm{~V}_{8} \mathrm{O}_{89}$ constituent. This design approach led to anodic and cathodic photocurrent densities of $+38.41 \mathrm{~mA} \mathrm{~cm}^{-2}\left(+0.76 \mathrm{~V}_{\mathrm{RHE}}\right)$ and $-2.48 \mathrm{~mA} \mathrm{~cm}^{-2}\left(0 \mathrm{~V}_{\mathrm{RHE}}\right)$, respectively. Accordingly, first, this heterojunction can be used either as photoanode or as photocathode with great performance for artificial photosynthesis, noting, second, that the anodic response reveals exceptionally high: more than $300 \%$ superior to excellent values previously reported in the literature.

Water splitting by photoelectrochemical cells (PECs) in the presence of light is a sustainable approach to directly convert solar energy into storable chemical energy $\left(\mathrm{H}_{2} \text { fuel }\right)^{1-5}$. Efforts to solve a number of deficiencies and to gain in performance have included modifying the electronic structure of the materials, constructing favorable surface structures with heterojunction, or controlling the morphology $y^{6,7}$. The heterojunction concept is actually an excellent alternative for designing materials with improved photocatalytic properties ${ }^{7}$, because promoting a good separation and transport of the photogenerated charges ${ }^{8,9}$. This is the case of bismuth vanadate- and bismuth oxide-based heterojunction systems like $\mathrm{BiVO}_{4} / \mathrm{Bi}_{4} \mathrm{~V}_{2} \mathrm{O}_{11}{ }^{10-12}, \mathrm{BiVO}_{4} / \mathrm{Bi}_{2} \mathrm{O}_{3}{ }^{13}, \alpha-\mathrm{Bi}_{4} \mathrm{~V}_{2} \mathrm{O}_{11} / \beta-\mathrm{Bi}_{4} \mathrm{~V}_{2} \mathrm{O}_{11}{ }^{14}$, $\mathrm{Bi}_{24} \mathrm{O}_{31} \mathrm{Br}_{10} / \mathrm{Bi}_{4} \mathrm{~V}_{2} \mathrm{O}_{11}{ }^{15}, \mathrm{CdS} / \mathrm{Bi}_{4} \mathrm{~V}_{2} \mathrm{O}_{11}{ }^{16}, \mathrm{Bi}_{2} \mathrm{O}_{3} / \mathrm{Bi}_{4} \mathrm{~V}_{2} \mathrm{O}_{11}{ }^{17}, \mathrm{Bi}_{2} \mathrm{O}_{3} / \mathrm{BiPO}_{4}{ }^{18}, \mathrm{WO}_{3} / \mathrm{BiVO}_{4} / \mathrm{TiO}_{2}{ }^{19}, \mathrm{BiOCl} / \mathrm{BiVO}_{4} / \mathrm{N}-$ $\mathrm{GQD}^{20}$, and $\mathrm{TiO}_{2} / \mathrm{BiVO}_{4} / \mathrm{SnO}_{2}{ }^{21}$ that have been tested. Important features such as band-gap energies in the visible spectrum range and the appropriate energy levels of the valence (and conduction) bands make bismuthvanadium oxides-based compounds attractive to be combined in $p-n$ PECs for water splitting ${ }^{10}$.

Overall, in this topic, different design models of PECs such as $p-n$ PEC, PEC/photovoltaic, PEC/electroplating devices and others ${ }^{9,22-24}$ have been proposed, with focus always on improving device performance. Among these configurations, the $p-n$ PECs formed by a $n$-type semiconductor photoanode and a $p$-type semiconductor photocathode are simpler approaches. The use of PECs with two (or more) light absorbers is advantageous

${ }^{1}$ Group of Ferroelectrics and Multifunctional Materials, Institute of Physics, Federal University of Uberlandia, Uberlândia, Minas Gerais 38408-100, Brazil. ²Physics Faculty/IMRE, University of Havana, 10400 Havana, Cuba. ${ }^{3}$ Laboratory of Photochemistry and Materials Science, Institute of Chemistry, Federal University of Uberlandia, Uberlândia, Minas Gerais 38408-100, Brazil. ${ }^{4}$ Multifunctional Electronic Materials and Devices Research Lab, Department of Electrical and Computer Engineering, College of Engineering, The University of Texas At San Antonio, San Antonio, TX 78249, USA. ${ }^{5}$ São Carlos Institute of Physics, University of São Paulo, São Carlos, São Paulo 13560-970, Brazil. 『email: santos@ufu.br 


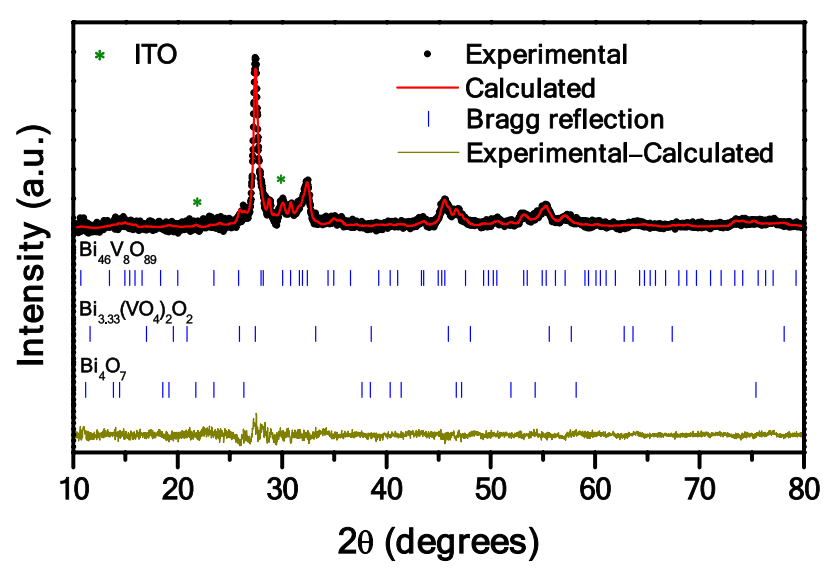

Figure 1. XRD pattern and Rietveld refinement of the prepared BVO film.

because of the reduction of the thermodynamic potential needed for water splitting into $\mathrm{O}_{2}\left(+1.23 \mathrm{~V}_{\mathrm{RHE}}\right)$ and $\mathrm{H}_{2}$ $\left(0 \mathrm{~V}_{\mathrm{RHE}}\right)^{11,25}$. In addition, configuration of the $p-n$ PEC also provides greater output photovoltage to form the $\mathrm{H}_{2}$ and $\mathrm{O}_{2}$ products from water splitting ${ }^{5}$. In order to successfully perform the photoelectrochemical decomposition of water without the need of applied potentials, we just note that the photovoltage of the cell must exceed $+1.23 \mathrm{~V}$ under light irradiation ${ }^{11}$.

With eyes on the bismuth- and vanadium-based materials, a multifunctional photoelectrode based on the unprecedented combination of $\mathrm{Bi}_{46} \mathrm{~V}_{8} \mathrm{O}_{89}, \mathrm{Bi}_{3.33}\left(\mathrm{VO}_{4}\right)_{2} \mathrm{O}_{2}$ and $\mathrm{Bi}_{4} \mathrm{O}_{7}$ was designed and constructed in this work. $\mathrm{Bi}_{46} \mathrm{~V}_{8} \mathrm{O}_{89}$ is an ionic conductor with a remarkable conductivity, where oxygen ion migration pathways include not only the diffusion of the vacancy through the $\mathrm{Bi}-\mathrm{O}$ sub-network, commonly found in $\delta-\mathrm{Bi}_{2} \mathrm{O}_{3}$ based superstructures, but also the exchange of $\mathrm{O}^{2-}$ between the $\mathrm{Bi}-\mathrm{O}$ and $\mathrm{V}-\mathrm{O}$ sub-networks ${ }^{26,27} \cdot \mathrm{Bi}_{3.33}\left(\mathrm{VO}_{4}\right)_{2} \mathrm{O}_{2}$ is a semiconductor-like material with an optical band-gap around $2.36 \mathrm{eV}$, and exhibits a great photocatalytic behavior for the decomposition of, e.g., phenol under visible light irradiation ${ }^{28} \cdot \mathrm{Bi}_{4} \mathrm{O}_{7}$ is also a semiconductor-like material, exhibiting a strong visible light absorption with an edge around $700 \mathrm{~nm}^{29}$. The energies of the conduction and valence bands were in this material estimated to be about $0.63 \mathrm{eV}$ and $2.52 \mathrm{eV}$ versus NHE (Normal Hydrogen Electrode), giving a band-gap value of about $1.89 \mathrm{eV}^{30}$. We show that when the $\mathrm{Bi}_{46} \mathrm{~V}_{8} \mathrm{O}_{89}$ ionic-conductor is coupled to $\mathrm{Bi}_{4} \mathrm{O}_{7} / \mathrm{Bi}_{3.33}\left(\mathrm{VO}_{4}\right)_{2} \mathrm{O}_{2}$, its spontaneous-like electrical polarization generates an electric field high enough to produce an inversion layer at the interface, ending with an increased efficiency for generation, transport and separation of the photogenerated charges. The consequence is observation of a super-enhanced photoelectrochemical activity due to the right combination of a rectifier contact and an inversion layer, enabling an adequate alignment of the energy bands. In addition, we demonstrate that nature of conductivity in this photoelectrode heterostructure can be also adjusted in a tuning-like way depending on the applied potential and frequency, the consequence of which is also discussed.

\section{Results}

Photoelectrode synthesis and characterization. One of the components targeted in this work is $\mathrm{Bi}_{4} \mathrm{O}_{7}$, and its synthesis on a large scale and high-purity grade is known to be a challenge. But, also known is that this oxide usually appears as an impurity during processing of other bismuth oxides ${ }^{29}$, and this was the approach considered here through controlling synthesis parameters. Briefly, particulate composite-like bismuthand vanadium-containing photoelectrode films, simply abbreviated as BVO, were produced from high-purity $\mathrm{Bi}_{5} \mathrm{O}(\mathrm{OH})_{9}\left(\mathrm{NO}_{3}\right)_{4}$ and $\mathrm{NH}_{4} \mathrm{VO}_{3}$ reagents, followed by deposition on transparent conducting indium tin oxide (ITO) coated glass, as described in the Experimental section. The films were characterized in terms of X-ray diffraction (XRD), Raman spectroscopy (RS), scanning electron microscopy (SEM), and diffuse reflectance spectra (DRS). Figure 1 shows the XRD pattern from the prepared $\mathrm{BVO}$ material, the data of which reveals presence of the three phases intended in this work: $\mathrm{Bi}_{46} \mathrm{~V}_{8} \mathrm{O}_{89}$ (ICSD 415113), $\mathrm{Bi}_{3.33}\left(\mathrm{VO}_{4}\right)_{2} \mathrm{O}_{2}$ (COD 1507777) and $\mathrm{Bi}_{4} \mathrm{O}_{7}$ (ICSD 51778). Indeed, getting the two former phases involved a careful control of the synthesis process, which showed a clear influence on the stoichiometry of the end product. That is, by using acetic acid ( $\mathrm{pH} \approx 2$ ), formation of the $\mathrm{Bi}_{46} \mathrm{~V}_{8} \mathrm{O}_{89}$ phase, which is self-doped with $\mathrm{Bi}^{5+}$, was verified. Furthermore, when ammonium hydroxide was added to change the $\mathrm{pH}$ to 8 , a decomposition of part of $\mathrm{Bi}_{46} \mathrm{~V}_{8} \mathrm{O}_{89}$ into $\mathrm{Bi}_{4} \mathrm{~V}_{2} \mathrm{O}_{11}$ was favored. Besides these bismuth- and vanadium-containing photoactive phases, diffraction peaks corresponding to the ITO substrate were also identified in Fig. 1 (ICSD 85084). Refinement of the XRD data by applying the Rietveld method allowed assessing the crystallographic parameters of these phases, and the results are presented in Table S1, remaining totally comparable with data from the literature ${ }^{26,28,31}$.

In order to get additional information about the BVO ternary heterostructure, Raman spectroscopy was performed, and the result is shown in Fig. 2. The data was fitted using a theoretical method based on the location of the curvature maxima in concave-down (CMCD) spectral regions of the recorded Raman spectrum ${ }^{32}$. The fitting curve of the measured spectrum (solid line) as well as the decomposed contributions into individual Lorentzian components (dashed lines) are also shown in Fig. 2. The peaks position for each Raman active mode (natural wavenumber, $\mathrm{cm}^{-1}$ ), obtained by the aforementioned CMCD method, and the assigned vibrational 


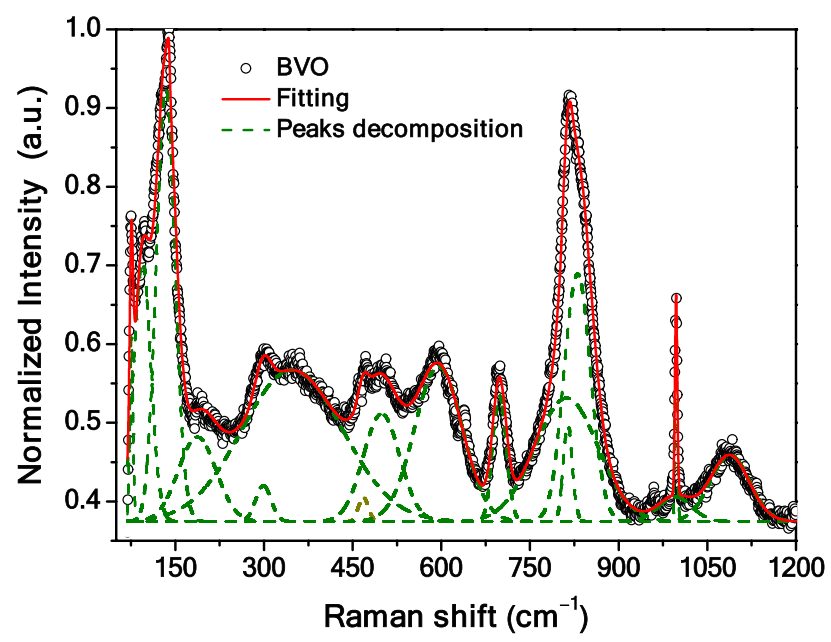

Figure 2. Measured Raman scattering spectrum (open symbols), together with the fitted spectrum (solid line) and the decomposed active modes (dashed lines) of the BVO film.

modes are summarized in Table S2. The peaks with long correlation-lengths found around 498.08 and $594.51 \mathrm{~cm}^{-1}$ are assigned to the $\mathrm{Bi}-\mathrm{O}\left(\mathrm{OBi}_{4}\right)$ vibrational mode, while those with short correlation-lengths observed at 75.61 , $94.03,133.63,186.31$ and $298.12 \mathrm{~cm}^{-1}$ are assigned to the $\mathrm{Bi}-\mathrm{O}\left(\mathrm{OBi}_{3}\right)$ vibrational mode ${ }^{33}$. In particular, the peak at $94.03 \mathrm{~cm}^{-1}$ is caused by the $\mathrm{Bi}^{(3-\mathrm{x})+}$ and $\mathrm{Bi}^{5+}$ species ${ }^{34}$. The bands at $347.02 \mathrm{~cm}^{-1}$ and $467.43 \mathrm{~cm}^{-1}$ are assigned to the $v_{2}$ and $v_{4}$ symmetric flexion modes of the $\mathrm{VO}_{4}$ tetrahedron, respectively ${ }^{33,35,36}$. The peak located at $698.17 \mathrm{~cm}^{-1}$ is attributed to the $v_{3}$ anti-symmetric mode of the $\mathrm{VO}_{4}$ tetrahedron, while the peaks at 810.96, 813.74 and $829.83 \mathrm{~cm}^{-1}$ are assigned to the $v_{1}$ symmetric mode of the $\mathrm{V}-\mathrm{O}$ bond $\mathrm{d}^{33,35,36}$. The Raman band located at $640.64 \mathrm{~cm}^{-1}$ is related to the double-coordinated oxygen atom of the $\mathrm{V}-\mathrm{O}-\mathrm{V}$ bond $\mathrm{d}^{33,35}$. Finally, bands related to the vanadyl oxygen expansion mode $\mathrm{V}^{4+}=\mathrm{O}$, located at 994.67 and $997.29 \mathrm{~cm}^{-1}$, and $\mathrm{V}^{5+}=\mathrm{O}$, located at $1,087.47 \mathrm{~cm}^{-1}$, were observed ${ }^{37}$. The presence of these bands suggests the existence of the two bismuth oxide vanadate phases, which is a consequence of the $\mathrm{OH}^{-}$action in the aqueous solution during synthesis control, as we mentioned above.

The following reaction (a) represents the synthesis process under acidic $\mathrm{pH}$ conditions, using acetic acid as a solvent for the reagent dilution.

(a) $46 \mathrm{Bi}_{5}(\mathrm{OH})_{9}\left(\mathrm{NO}_{3}\right)_{4}+40 \mathrm{NH}_{4} \mathrm{VO}_{3} \rightarrow 5 \mathrm{Bi}_{46} \mathrm{~V}_{8} \mathrm{O}_{89}+177 \mathrm{O}_{2}+112 \mathrm{~N}_{2}+287 \mathrm{H}_{2} \mathrm{O}$

The $\mathrm{Bi}_{5} \mathrm{O}(\mathrm{OH})_{9}\left(\mathrm{NO}_{3}\right)_{4}$ compound is formed after mixing of bismuth nitrate and bismuth oxide, having the used reagent in the present work about $79 \%$ of $\mathrm{Bi}_{2} \mathrm{O}_{3}$ dosage. After reacting with $\mathrm{NH}_{4} \mathrm{VO}_{3}$, it would result in the formation of $\mathrm{Bi}_{46} \mathrm{~V}_{8} \mathrm{O}_{89}$. However, for a conversion of $\sim 100 \%$ of $\mathrm{Bi}_{46} \mathrm{~V}_{8} \mathrm{O}_{89}$, as described in the previous reaction, the crystallization process would have to be necessarily performed at higher temperatures $\left(\geq 700^{\circ} \mathrm{C}\right)^{26}$; nevertheless, as the correction was carried out under a basic $\mathrm{pH}$ condition, according to the reactions (b) and (c), and the crystallization of the BVO film was performed at $450{ }^{\circ} \mathrm{C}$, it was already expected that other crystalline phases would be formed during the thermal decomposition ${ }^{26,27}$. Furthermore, it is known that corner sharing $\mathrm{BiO}_{3}^{-} \mathrm{e}$ $\mathrm{VO}_{3}^{-}$ions could give rise to mixed oxides ${ }^{38-40}\left(\mathrm{Bi}_{3.33}\left(\mathrm{VO}_{4}\right)_{2} \mathrm{O}_{2}\right.$ and $\left.\mathrm{Bi}_{4} \mathrm{O}_{7}\right)$ by the action of hydroxyl radicals from the $\mathrm{NH}_{4} \mathrm{OH}$ base used in the synthesis process, as can be seen by the following reactions (b) and (c):

(b) $4 \mathrm{BiO}_{3}^{-}+2 \mathrm{OH}^{-} \rightarrow \mathrm{Bi}_{4} \mathrm{O}_{7}+3 \mathrm{O}_{2}+\mathrm{H}_{2} \mathrm{O}$

(c) $3.33 \mathrm{BiO}_{3}^{-}+2 \mathrm{VO}_{3}^{-}+\mathrm{OH}^{-} \rightarrow \mathrm{Bi}_{3.33}\left(\mathrm{VO}_{4}\right)_{2} \mathrm{O}_{2}+3.245 \mathrm{O}_{2}+0.5 \mathrm{H}_{2} \mathrm{O}$

After such reactions, citric acid was used in order to stabilize the bismuth metallic ions during the drying process. On the other hand, in order to provide additional support for the good correspondence between the observed results from XRD data and Raman spectroscopy, complementary structural analysis has been considered, which involves two fundamental parameters that can be used to get further structural information regarding the synthesized phases, as is the case of the average crystallite size (D) and structural micro-strain $(\epsilon)$. Both parameters were estimated from the XRD pattern using the Williamson-Hall equation: ${ }^{41,42}$

$$
\beta_{\mathrm{hkl}} \cos \theta=\frac{\mathrm{K} \lambda}{\mathrm{D}}+4 \epsilon \sin \theta
$$

where $\mathrm{K}$ is a proportionality constant related to the particle geometry, $\lambda$ is the wavelength, $\theta$ is the Bragg's angle and $\beta_{\mathrm{hkl}}$ represents the full-width at half-maximum of the diffraction peaks. The results are shown in Table 1. 


\begin{tabular}{|c|l|l|c|}
\hline \multirow{2}{*}{ Parameters } & \multicolumn{2}{|l|}{ Crystalline phases } \\
\cline { 2 - 4 } & $\mathbf{B i}_{46} \mathbf{V}_{\mathbf{8}} \mathbf{O}_{\mathbf{8 9}}$ & $\mathbf{B i}_{3.33}\left(\mathbf{V O}_{4}\right)_{2} \mathbf{O}_{2}$ & $\mathbf{B i}_{4} \mathbf{O}_{7}$ \\
\hline $\mathrm{D}\left(10^{-9} \mathrm{~m}\right)$ & 38.08 & 25.66 & 33.15 \\
\hline$\epsilon\left(10^{-4} \mathrm{~m}\right)$ & 4.87 & -2.28 & 3.40 \\
\hline
\end{tabular}

Table 1. Average crystallite size (D) and structural micro-strain $(\epsilon)$ obtained for the film BVO, by using the Williamson-Hall equation.
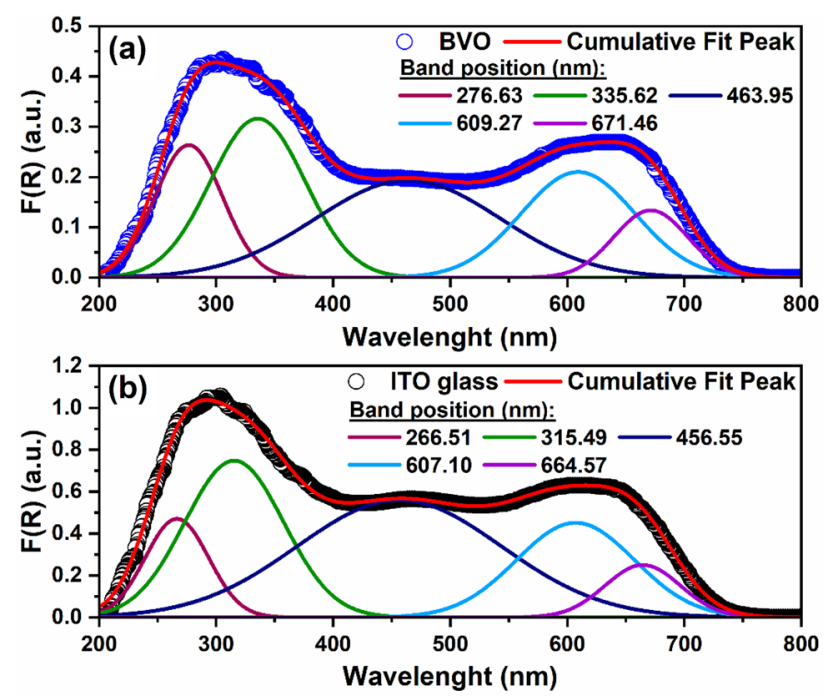

Figure 3. Kubelka-Munk absorbance: (a) BVO film and (b) ITO glass.

As can be seen, while a positive strain for $\mathrm{Bi}_{46} \mathrm{~V}_{8} \mathrm{O}_{89}$ and $\mathrm{Bi}_{4} \mathrm{O}_{7}$ phases has been observed, a structural selfdoping with $\mathrm{Bi}^{5+}$ ions, with ionic radius around $76 \mathrm{pm}$ (or $0.76 \AA$ ), causes a negative strain for the $\mathrm{Bi}_{3.33}\left(\mathrm{VO}_{4}\right)_{2} \mathrm{O}_{2}$ phase. This leads to an increase of the unit-cell volume in $\mathrm{Bi}_{46} \mathrm{~V}_{8} \mathrm{O}_{89}$ and $\mathrm{Bi}_{4} \mathrm{O}_{7}$ and a decrease of volume for $\mathrm{Bi}_{3.33}\left(\mathrm{VO}_{4}\right)_{2} \mathrm{O}_{2}$, the consequence of which is a reduced average crystallite size for the latter. Due to the bismuth deficiency, the lattice oxygen ions $\left(\mathrm{O}^{2-}\right)$ undergo a charge transfer with the $\mathrm{Bi}^{3+}$ ions on the surface of the $\mathrm{BVO}$ heterostructure. Therefore, due to the ions' mobility, we consider that there is a double valence fluctuation scheme involving the change of two electrons on the surface. The double valence variation process, as described in the following reaction (c), occurs due to the dimerization of the ligand holes $\left(h^{+}\right)$caused by direct ligand-ligand hybridization, which is expected in perovskite-type structures in which there is an oxygen accumulation nearby. This process occurs, in particular, when the spin density of $\mathrm{Bi}^{3+}$ is small and it participates in the double valence fluctuation.

(c) $\mathrm{Bi}^{3+}+2 \mathrm{O}^{2-} \rightarrow \mathrm{Bi}^{5+}+\mathrm{O}_{2}^{2-}$

Under thermal evacuation, the bismuth oxide with the $\mathrm{Bi}^{3+}\left(6 \mathrm{p}^{\circ}\right)$ electronic configuration is transformed into its $\mathrm{Bi}^{5+}\left(6 \mathrm{~s}^{\circ}\right)$ state by double valence flotation ${ }^{43,44}$. For complementary information, SEM image of the films is presented in Figure S1, the result of which revealed the BVO material to consist of islands of self-assembled nanoplates, forming nano-porous sponges. In addition, the cross-sectional view, shown in Figure S2, indicated to be dealing with films showing a thickness of about $\sim 10 \mathrm{~m}$.

On the other hand, the DRS data represented through the transmittance (T) and reflectance (R) spectra, whose results are shown in Figure S3a-b, revealed that the displacement of the bands occurred after the deposition of the BVO film on the ITO. The BVO film was quite rough on the surface due to the higher reflectance, compared to the ITO glass. According to the literature, and some data collected in our Laboratory, values of the direct band-gap energies for the model (individual) compounds are: $1.89 \mathrm{eV}$ for $\mathrm{Bi}_{4} \mathrm{O}_{7}, 2.36 \mathrm{eV}$ for $\mathrm{Bi}_{3.33}\left(\mathrm{VO}_{4}\right)_{2} \mathrm{O}_{2}$ and $2.93 \mathrm{eV}$ for $\mathrm{Bi}_{46} \mathrm{~V}_{8} \mathrm{O}_{89}{ }^{27,28,30}$. These values are comparable to those estimated in this work from Figure S3c, except for $\mathrm{Bi}_{4} \mathrm{O}_{7}$, where the synthesis procedure was determinant in reducing its value. In any case, these results indicate that all the three components in the BVO heterojunction can be individually excited by visible light to produce the reactive species, that is to say, electrons and holes needed to trigger water splitting.

Regarding the main interest spectrum, i.e. Kubelka-Munk absorbance (F(R)), we proceeded with a Gaussian deconvolution of the absorption bands, the results of which are shown in Fig. 3. Five absorption bands were identified, which presented wavelength displacements towards the region of the visible spectrum for the BVO film. Such a displacement is caused by defects in the crystalline structure of the BVO, and it is expected to promote 


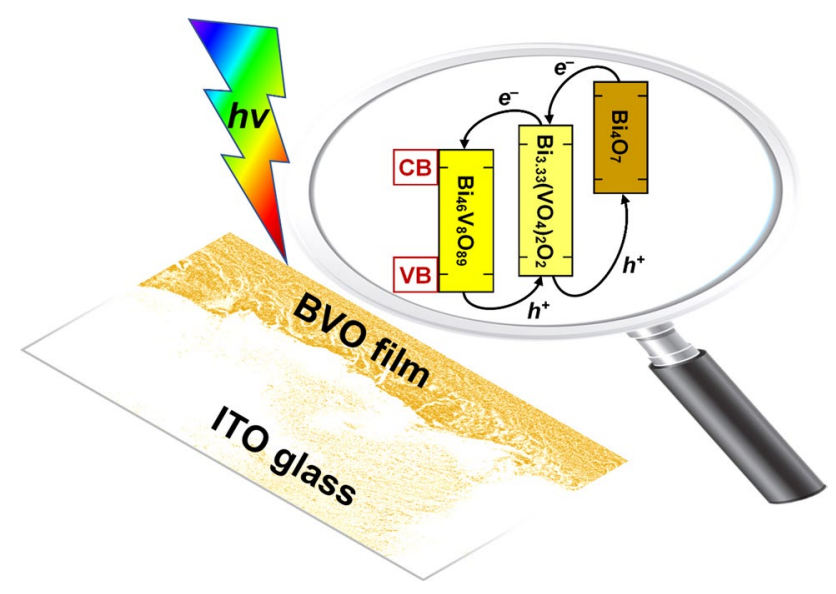

Figure 4. Alignment of conduction (CB) and valence (VB) bands for the $\mathrm{Bi}_{4} \mathrm{O}_{7}-\mathrm{Bi}_{3.33}\left(\mathrm{VO}_{4}\right)_{2} \mathrm{O}_{2}-\mathrm{Bi}_{46} \mathrm{~V}_{8} \mathrm{O}_{89}$ (abbreviated as BVO) particulate composite-like ternary heterojunction.

donor (or acceptor) states between the energy bands, giving rise to certain charge trap states between the bands. The charge carriers trapping in these states could play a crucial role in the optical and photoelectrochemical properties of the BVO film ${ }^{45}$.

The adequate alignment of the conduction (CB) and valence (VB) bands applying in this situation is briefly outlined in Fig. 4 (with additional details given later).

The results presented in the following refer to data extracted from Mott-Schottky, photoelectrochemical performance and impedance spectroscopy measurements, aimed at getting insights into the materials chemistrycontrolled electrical and electrochemical responses from these heterojunction-structured BVO films. All these experiments were conducted using a standard three-electrode cell configuration ${ }^{46}$, with an $\mathrm{Ag} / \mathrm{AgCl}(3.0 \mathrm{M}$ $\mathrm{KCl})$ reference electrode, a platinum metalized FTO substrate as the counter electrode, and the BVO film acting as the working electrode (as described in Methods). For the sake of a direct comparison, the electrochemical performance and impedance data were collected under both dark and illumination conditions ${ }^{46}$.

Mott-Schottky data. The conductivity characteristics of the heterojunction-structured BVO material were partly elucidated by the Mott-Schottky electrochemical characterization, and interpreted through the mathematical model described by the equation below:

$$
\mathrm{Cp}^{-2}=\left(\frac{2}{\varepsilon \varepsilon_{0} A^{2} e \mathrm{~N}_{\mathrm{D}}}\right)\left(\mathrm{V}-\mathrm{V}_{\mathrm{fb}}-\frac{\mathrm{k}_{\mathrm{B}} \mathrm{T}}{\mathrm{e}}\right)
$$

from which a linear behavior between the inverse of the square capacitance $\left(\mathrm{Cp}^{-2}\right)$ of the space-charge layer and the applied potential $(\mathrm{V})$ is predicted. In this expression, $\mathrm{N}_{\mathrm{D}}$ is the number of donor ions, $\mathrm{k}_{\mathrm{B}}$ the Boltzmann's constant, $\varepsilon$ the dielectric constant of the semiconductor, $A$ the area of the electrode, $\varepsilon_{0}$ the dielectric permittivity of free space, $T$ the absolute temperature, $e$ the electronic charge and $V_{\mathrm{fb}}$ the flat-band potential ${ }^{47,48}$.

The Mott-Schottky results from the BVO film are illustrated in Fig. 5 , and the nature ( $n$ or $p$ ) of conductivity from each component is there identified. The data reveal that, at low frequencies, in the range of $1-100 \mathrm{~Hz}$ (Fig. 4, left-hand side), the photoelectrode mostly shows $n$-type conductivity (straight lines with positive slope) for potential values $<+1.2 \mathrm{~V}_{\mathrm{RHE}}$. For values $>+1.2 \mathrm{~V}_{\mathrm{RHE}}$, however, an inversion of polarity is observed, which is related to the contact of $n-\mathrm{Bi}_{4} \mathrm{O}_{7}, n-\mathrm{Bi}_{3.33}\left(\mathrm{VO}_{4}\right)_{2} \mathrm{O}_{2}$ and $n-\mathrm{Bi}_{46} \mathrm{~V}_{8} \mathrm{O}_{89}$, resulting in the formation of a spatialcharge region at the $\mathrm{Bi}_{3.33}\left(\mathrm{VO}_{4}\right)_{2} \mathrm{O}_{2} / \mathrm{Bi}_{46} \mathrm{~V}_{8} \mathrm{O}_{89}$ interface of this minority $h^{+}$-charged junction so as reversing the conductivity of $\mathrm{Bi}_{46} \mathrm{~V}_{8} \mathrm{O}_{89}$ to $p$-type. For high frequencies, in the range of 1-100 kHz (Fig. 4, right-hand side), a modification to mostly $p$-type conductivity occurs (straight lines with negative slope) towards low potential values, with a polarity inversion occurring at $+0.8 \mathrm{~V}_{\mathrm{RHE}}$ while increasing the potential. In this case, the inversion layer acts in the opposite way, because when the $p-\mathrm{Bi}_{46} \mathrm{~V}_{8} \mathrm{O}_{89}$ structure is in contact with the $p-\mathrm{Bi}_{3.33}\left(\mathrm{VO}_{4}\right)_{2} \mathrm{O}_{2}$ one, the spatial charge region at the interface of the junction will be charged with a minority of negative $\left(e^{-}\right)$charges, and the conductivity of $\mathrm{Bi}_{46} \mathrm{~V}_{8} \mathrm{O}_{89}$ will be of $n$-type.

Regarding particularly $\mathrm{Bi}_{4} \mathrm{O}_{7}$, an additional relevant information seen in this Figure is the polarity change this component shows at $100 \mathrm{~Hz}$ and $100 \mathrm{kHz}$, indicating formation of a dipole moment at the $\mathrm{Bi}_{4} \mathrm{O}_{7} / \mathrm{Bi}_{3.33}\left(\mathrm{VO}_{4}\right)_{2} \mathrm{O}_{2}$ interface, with apparently a minority of positive $\left(h^{+}\right)$charges at $100 \mathrm{~Hz}$, and a minority of negative $\left(e^{-}\right)$charges at $100 \mathrm{kHz}$. According to the literature, the inversion layer cannot be detected for thin films with a single semiconductor ${ }^{11}$. This suggests that this process occurs at the interface between the materials constituting the heterojunction, revealing that in the inversion layer the BVO film may act as a photocathode. For this reason, besides the originally-planned tests for photoanode applications (the results of which are presented in the next section), behavior of the $\mathrm{Bi}_{4} \mathrm{O}_{7} / \mathrm{Bi}_{3.33}\left(\mathrm{VO}_{4}\right)_{2} \mathrm{O}_{2} / \mathrm{Bi}_{46} \mathrm{~V}_{8} \mathrm{O}_{89}$ heterojunction as photocathode was also checked and analyzed through current-potential curves (Figure S4). The BVO heterostructure exhibited a notable photocurrent typical 


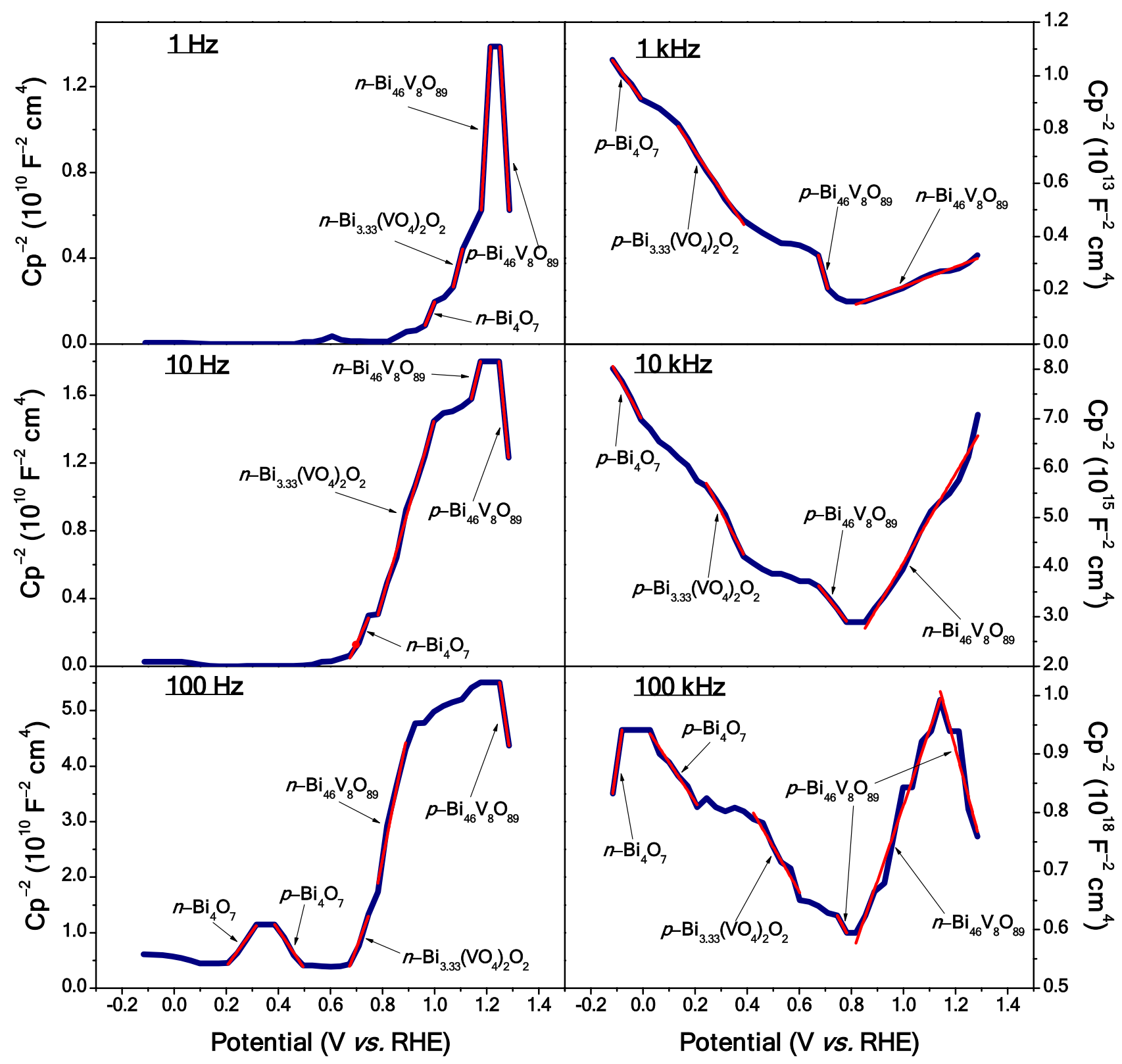

Figure 5. Mott-Schottky plots. Variation of capacitance (C) with the applied potential in a $\mathrm{Na}_{2} \mathrm{SO}_{4}$ aqueous solution (with $0.5 \mathrm{M}$ and $\mathrm{pH}=6.6$ ), as extracted from the Mott-Schottky experiments conducted on the BVO film at different frequencies.

of $p$-type semiconductors at cathodic potential, with a density of- $2.48 \mathrm{~mA} \mathrm{~cm}^{-2}$ at $0 \mathrm{~V}_{\mathrm{RHE}}$, proving effectively photoactivity of this heterojunction structure as photocathode.

From the application of the Mott-Schottky mathematical model, the conduction energy bands (CB) can be measured as the flat-band potential $\left(\mathrm{V}_{\mathrm{fb}}\right)$ and, as a consequence, the valence energy bands (VB) position was calculated by summing the optical band-gap energy and $\mathrm{V}_{\mathrm{fb}}$ for each component. The $\mathrm{CB}$ values obtained at different frequencies for the $\mathrm{Bi}_{4} \mathrm{O}_{7}, \mathrm{Bi}_{3.33}\left(\mathrm{VO}_{4}\right)_{2} \mathrm{O}_{2}$ and $\mathrm{Bi}_{46} \mathrm{~V}_{8} \mathrm{O}_{89}$ phases were, respectively: $1 \mathrm{~Hz}(+0.94,+1.02$ and $\left.+1.15 \mathrm{~V}_{\mathrm{RHE}}\right), 10 \mathrm{~Hz}\left(+0.66,+0.73\right.$ and $\left.+0.89 \mathrm{~V}_{\mathrm{RHE}}\right), 100 \mathrm{~Hz}\left(+0.14,+0.64\right.$ and $\left.+0.70 \mathrm{~V}_{\mathrm{RHE}}\right), 1 \mathrm{kHz}(+0.69$, +0.69 and $\left.+0.77 \mathrm{~V}_{\mathrm{RHE}}\right), 10 \mathrm{kHz}\left(+0.72,+0.81\right.$ and $\left.+1.22 \mathrm{~V}_{\mathrm{RHE}}\right)$ and $100 \mathrm{kHz}\left(+1.41,+1.47\right.$ and $\left.+1.50 \mathrm{~V}_{\mathrm{RHE}}\right)$. On the other hand, the obtained $\mathrm{VB}$ values for $\mathrm{Bi}_{4} \mathrm{O}_{7}, \mathrm{Bi}_{3.33}\left(\mathrm{VO}_{4}\right)_{2} \mathrm{O}_{2}$ and $\mathrm{Bi}_{46} \mathrm{~V}_{8} \mathrm{O}_{89}$ are, respectively: at $1 \mathrm{~Hz}$ $\left(+1.73,+3.33\right.$ and $\left.+3.81 \mathrm{~V}_{\mathrm{RHE}}\right), 10 \mathrm{~Hz}\left(+1.45,+3.04\right.$ and $\left.+3.55 \mathrm{~V}_{\mathrm{RHE}}\right), 100 \mathrm{~Hz}\left(+0.93,+2.95\right.$ and $\left.+3.36 \mathrm{~V}_{\mathrm{RHE}}\right)$, $1 \mathrm{kHz}\left(+1.48,+3.00\right.$ and $\left.+3.43 \mathrm{~V}_{\mathrm{RHE}}\right), 10 \mathrm{kHz}\left(+1.51,+3.12\right.$ and $\left.+3.88 \mathrm{~V}_{\mathrm{RHE}}\right)$ and $100 \mathrm{kHz}(+2.20,+3.78$ and $\left.+4.16 \mathrm{~V}_{\mathrm{RHE}}\right)$. Based on these values, we designed the potential energy diagram showing the alignment of the $\mathrm{CB}$ and $\mathrm{VB}$ bands for the three $\mathrm{Bi}_{4} \mathrm{O}_{7}, \mathrm{Bi}_{3.33}\left(\mathrm{VO}_{4}\right)_{2} \mathrm{O}_{2}$ and $\mathrm{Bi}_{46} \mathrm{~V}_{8} \mathrm{O}_{89}$ phases and the figure will be shown later, with an additional discussion. The $\mathrm{CB}$ and $\mathrm{VB}$ for the $\mathrm{Bi}_{4} \mathrm{O}_{7}$ phase are more negative than the corresponding bands for $\mathrm{Bi}_{3.33}\left(\mathrm{VO}_{4}\right)_{2} \mathrm{O}_{2}$, while the $\mathrm{CB}$ and $\mathrm{VB}$ of $\mathrm{Bi}_{3.33}\left(\mathrm{VO}_{4}\right)_{2} \mathrm{O}_{2}$ are more negative than the corresponding bands of $\mathrm{Bi}_{46} \mathrm{~V}_{8} \mathrm{O}_{89}$; this observed behavior favors the easy injection of electrons from the $\mathrm{CB}$ of $\mathrm{Bi}_{4} \mathrm{O}_{7}$ to that of $\mathrm{Bi}_{3.33}\left(\mathrm{VO}_{4}\right)_{2} \mathrm{O}_{2}$ and $\mathrm{CB}$ of $\mathrm{Bi}_{3.33}\left(\mathrm{VO}_{4}\right)_{2} \mathrm{O}_{2}$ to that of $\mathrm{Bi}_{46} \mathrm{~V}_{8} \mathrm{O}_{89}$ in the heterostructure. 


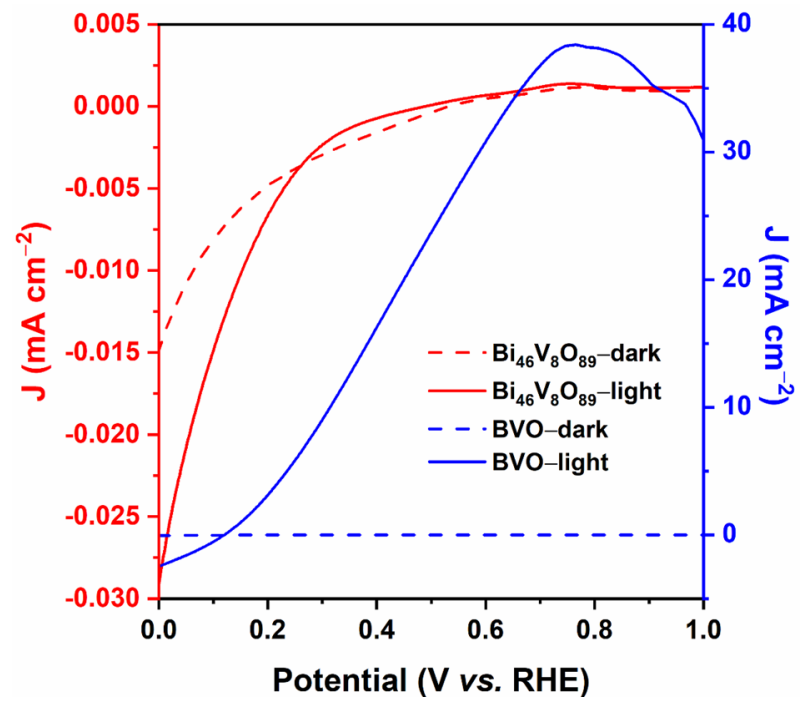

Figure 6. Photoelectrochemical characteristic of the photoelectrode. Current-potential curves for the prepared BVO film, acting as photoanode. Measurement conditions: active area of $0.2 \mathrm{~cm}^{2}$, and $0.5 \mathrm{M} \mathrm{Na}_{2} \mathrm{SO}_{4}$ electrolyte $(\mathrm{pH}=6.6)$. Light Source: Xe Lamp $\left(\lambda>450 \mathrm{~nm}, 100 \mathrm{~mW} \mathrm{~cm}^{-2}\right)$, scan rate of $20 \mathrm{mV} \mathrm{s}^{-1}$ from low to high potential, in back illumination mode.

Photoelectrochemical performance and impedance spectroscopy. The electrochemical performance characteristics of the BVO electrode, tested as photoanode, under dark and illumination conditions are depicted in Fig. 6. Photoactivity of this working electrode is clear, noting that, under light irradiation, the extracted data of anodic (peak value) photocurrent density is $+38.41 \mathrm{~mA} \mathrm{~cm}^{-2}\left(+0.76 \mathrm{~V}_{\mathrm{RHE}}\right)$. Furthermore, the photocurrent density values obtained for the BVO heterostructure were significantly higher than the values for $\mathrm{Bi}_{46} \mathrm{~V}_{8} \mathrm{O}_{89}$, indicating that the formation of the heterojunction improves the charges separation and transport processes. Notice that the result for water oxidation is actually telling, as revealing to be $393 \%$ greater than that reported, for instance, for one of the best photoanodes based on parent $\mathrm{W}-\mathrm{BiVO}_{4} / \mathrm{V}_{2} \mathrm{O}_{5}$ films, which achieved a high but comparatively-quite lower photocurrent density of $+7.79 \mathrm{~mA} \mathrm{~cm}^{-2}\left(+1.23 \mathrm{~V}_{\mathrm{RHE}}\right)^{49}$.

These results, showing photoactivity of the BVO film either as photocathode or as photoanode are outstanding because revealing the bifunctionality of this heterojunction-structured photoelectrode for water splitting into $\mathrm{H}_{2}$ and $\mathrm{O}_{2}$. In addition, the highest (peak) value we obtained for the HC-STH (half-cell solar-to-hydrogen efficiency) of the BVO film was about $19.75 \%$ at $+0.65 \mathrm{~V}_{\mathrm{RHE}}$ (Figure S5). All these results demonstrate that the photoelectrode we built here can promote the photoelectrochemical oxidation of water in $\mathrm{O}_{2}$, and is also photoactive in the reduction reaction of water to produce renewable $\mathrm{H}_{2}$ fuel.

We would like to point out that in the region of the visible spectrum, the photoelectrode showed a light harvesting efficiency (LHE) from 36.67 to $47.23 \%$ and separation charges $\left(\eta_{\text {sep }}\right)$ around $48 \%$, at applied potentials from 0.5 to $0.8 \mathrm{~V}_{\mathrm{RHE}}$. Traditionally, the thermodynamic potential required for the water decomposition reaction is nearly $1.23 \mathrm{~V}_{\mathrm{RHE}}$. Because of the superpotentials at the cathode and anode, a voltage higher than $1.6 \mathrm{~V}$ is required for the electrolyzer to operate under a current density of around $1 \mathrm{~A} \mathrm{~cm}^{-2}$. In this case, almost $33.5-40 \%$ of electricity can be lost, resulting in a low overall energy conversion efficiency ${ }^{50,51}$. In practice, in order to minimize the energy loss, water electrolysis should be performed in highly acidic or alkaline conditions ${ }^{52}$. However, in this work, the data presented in Fig. 7 (representing the Tafel's plot), suggest that the action of superoxide ions $\left(\mathrm{O}^{2-}\right)$, resulting from the first redox step, can act in the second redox step (where a drop in photocurrent density occurs) in order to increase the potential energy necessary for the kinetic process of separation/transfer of photogenerated charges. Therefore, water splitting can be conducted in a sustainable manner in an electrochemical reaction.

The excess potential $(\eta)$ was estimated by the intersection of the anodic and cathodic inclinations and, according to the Tafel's kinetic-electrochemical model, is represented by the Eq. (3), where J is the current density, a represents the excess of anodic and cathodic potential, and $\beta$ is the Tafel's slope of the anodic (or cathodic) reaction ${ }^{53}$.

$$
\eta=\alpha \pm \beta \times \ln |J|
$$

This mathematical model is based on the kinetics and thermodynamics of the reactions involved on the surface of the photoelectrode, making possible to predict the potential and density of corrosion current by extrapolating the anodic and cathodic slopes ${ }^{54}$. In general, the higher the value of $\eta$ the better the anti-corrosion properties. 54 From the Tafel's plot shown in Fig. 7 it was possible to obtain some parameters, which are summarized in Table 2.

In particular, the photoelectrode under illumination reached a value of $\eta=2.07 \mathrm{~V}_{\mathrm{RHE}}$, well above the aforementioned minimum potential. In addition, values of the operational potential $\left(\mathrm{V}_{\mathrm{op}}\right)$ required for water splitting at a given current density $(\mathrm{J})$ were obtained by the Eq. $(4)^{55}$, and are also listed in Table 2. 

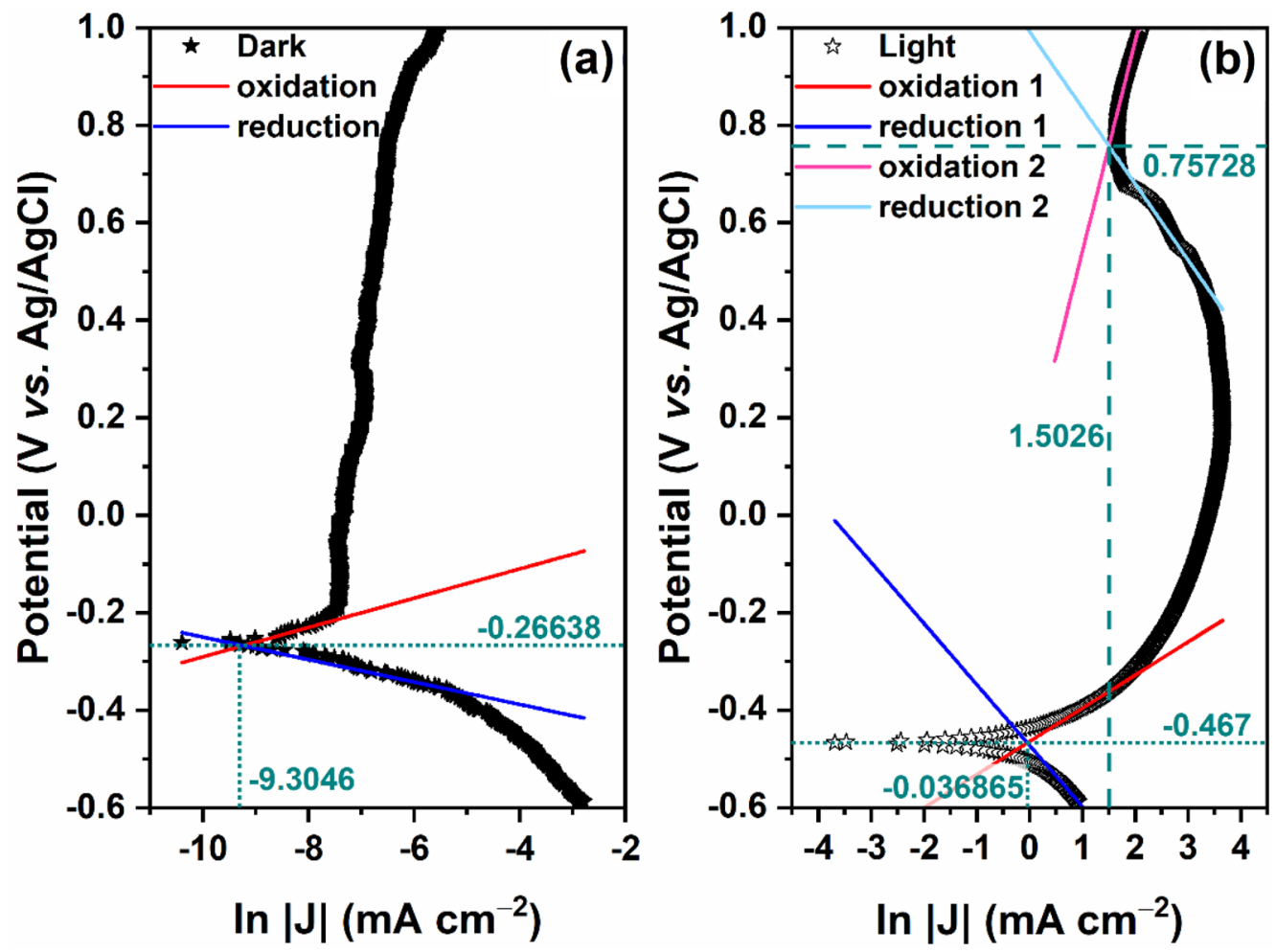

Figure 7. Tafel's plot: (a) dark and (b) light.

\begin{tabular}{|l|l|l|c|l|l|l|l|}
\hline \multirow{2}{*}{ Conditions } & \multicolumn{6}{|l|}{ Parameters } \\
\cline { 2 - 8 } & $\boldsymbol{\beta}_{\text {anodic }}$ & $\boldsymbol{\beta}_{\text {cathodic }}$ & $\boldsymbol{\alpha}_{\text {anodic }}$ & $\boldsymbol{\alpha}_{\text {cathodic }}$ & $\eta\left(\mathbf{V}_{\text {RHE }}\right)$ & $\mathbf{J}_{\text {corr }}\left(\mathbf{m A ~ c m}^{-2}\right)$ & $\mathbf{V}_{\text {op }}\left(\mathbf{V}_{\text {RHE }}\right)$ \\
\hline Dark & 0.029 & -0.023 & 0.010 & -0.480 & 1.05 & $9.1001 \mathrm{E}-5$ & 1.19 \\
\hline Light 1 & 0.068 & -0.125 & -0.464 & -0.472 & 0.84 & 0.9638 & 1.24 \\
\hline Light 2 & 0.431 & -0.156 & 0.110 & 0.992 & 2.07 & 4.4933 & 1.67 \\
\hline
\end{tabular}

Table 2. Parameters obtained from the Tafel plots for the BVO photoelectrode.

$$
\mathrm{V}_{\text {op }}=1.23+\left(\beta_{\text {anodic }} \times \ln \left|J_{\text {anodic }}\right|\right)+\left(\beta_{\text {cathodic }} \times \ln \left|J_{\text {cathodic }}\right|\right)+\left(\mathrm{J} \times \mathrm{A} \times \mathrm{R}_{\mathrm{p}}\right)
$$

The A parameter is the electrode area and $R_{p}$ represents the polarization resistance, which is obtained by the Eq. $(5)^{56}$.

$$
R_{p}=\left|\frac{\left(\beta_{\text {anodic }} \times \beta_{\text {cathodic }}\right)}{2.3 \times J_{\text {corr }} \times\left(\beta_{\text {anodic }}+\beta_{\text {cathodic }}\right)}\right|
$$

Notice that the values of $V_{\text {op }}$ and $\eta$ are close each other, showing excellent agreement with the expected data from the Tafel's plot towards the explored current densities. At the operating point, the efficiency for energy conversion $\left(\mathrm{PCE}=\mathrm{V}_{\mathrm{op}} \times \mathrm{J}_{\mathrm{op}} / \mathrm{P}\right)$ was estimated to be around 9.3\%. Regarding the high density of photogenerated current (high HC-STH efficiency) we have reported, a reasonable approach was described in this manuscript, that is, when $\mathrm{Bi}_{46} \mathrm{~V}_{8} \mathrm{O}_{89}$ comes into contact with the $\mathrm{Bi}_{4} \mathrm{O}_{7} / \mathrm{Bi}_{3.33}\left(\mathrm{VO}_{4}\right)_{2} \mathrm{O}_{2}$ interface, an adjustable virtual $p-n-p$ or $n-p-n$ junction is created, with the rectifying contact acting afterward as a conventional $p-n$ junction. For this reason, photogenerated charges can be efficiently separated by the ternary heterostructure, thus providing such a high density of photogenerated current. At the microscopic level, moreover, the following mechanisms may be also taken into consideration. It is well-known that the efficiency of the photogenerated $e^{-} / h^{+}$pairs separation is a critical factor for the photoelectrochemical performance ${ }^{39}$. Because of the $\mathrm{Bi}^{3+}$ and $\mathrm{Bi}^{5+}$ coexistence in the present BVO material, there is a scenario with bridges for local charge transfer and to reinforce the photogenerated electrons flow. Furthermore, $\mathrm{Bi}^{5+}$ should act as a charge trap for electrons, thus delaying the recombination of electrons and photogenerated holes ${ }^{39,57}$. For the same reason (the ions coexistence), and with $\mathrm{Bi}_{4} \mathrm{O}_{7}$ acting as a photosensitizer, singlet oxygen is formed after excitation by a triplet-triplet energy transfer step. This this kind of electrophilic oxygen plays also an important role in increasing the efficiency in the photoelectrochemical oxidation process, leading to an improvement in the HC-STH efficiency for energy conversion ${ }^{38,57}$. 


\begin{tabular}{|l|l|l|l|l|l|l|l|c|}
\hline \multirow{3}{*}{ Condition } & \multicolumn{9}{|l|}{ Electrochemical parameters } & $\mathbf{R s}(\boldsymbol{\Omega})$ & $\mathbf{R}_{\mathbf{1}}(\boldsymbol{\Omega})$ & $\mathrm{C}_{\mathbf{1}}(\boldsymbol{\mu} \mathbf{F})$ & $\mathbf{R}_{\mathbf{2}}(\boldsymbol{\Omega})$ & $\mathbf{C}_{\mathbf{2}}(\boldsymbol{\mu} \mathbf{F})$ & $\mathbf{R}_{\mathbf{3}}(\boldsymbol{\Omega})$ & $\mathrm{C}_{\mathbf{3}}(\boldsymbol{\mu} \mathbf{F})$ & $\tau_{2}(\mathbf{m s})$ \\
\hline Dark & 0.0 & 4,831 & 14.22 & 77.1 & 0.009 & $3,147.7$ & 55.8 & 0.0007 \\
\hline Light & 0.0 & 13.73 & 1.92 & 1916.4 & 25.72 & 21.2 & 0.03 & 49.3 \\
\hline
\end{tabular}

Table 3. Electrochemical parameters derived from Nyquist plots, according to the impedance measurements performed on the BVO photoelectrode.

Further insights into the feature of electrical transport process across the photoelectrode can be theoretically also obtained via electrochemical impedance spectroscopy (EIS). The measurements were carried out with a $20 \mathrm{mV}$ alternating-current $(\mathrm{AC})$ potential, together with a direct-current (DC bias) potential at $+1.23 \mathrm{~V}_{\mathrm{RHE}}$. The measured impedance data were processed using Nyquist plots (as observed in Figure S6), from which incidence of three semicircles was noted and simulated using an appropriate professional software (NOVA 2.1.3-Metrohm Autolab BV, Netherlands). The impedance data shown in Figure S6 have been fitted by the equivalent circuit represented in Figure S7, where a non-ideal Debye model involving three resistance-constant phase elements ( Ri-Qi) networks, all connected in series, with each set of $\mathrm{R}$ and $\mathrm{Q}$ elements linked in parallel, plus a series resistance (Rs) coupled, has been considered, being Rs the resistance of the used solution $\left(\mathrm{Na}_{2} \mathrm{SO}_{4}, 0.6 \mathrm{M}\right)$. In practice, materials whose impedance data follow the non-ideal model show depressed semicircles below the real axis in Nyquist plots for $(1-n) / 2$ angles. For $n=1$, such a model reduces to the classical Debye's scenario. In our work, we verified $n$ values to be in the range of 0.69-0.96, approaching to unity for the high-frequency semicircle. Table 3 summarize the electrochemical parameters derived from Nyquist plots, according to the impedance measurements performed on the BVO photoelectrode.

The equivalent values we finally found for capacitance fall in the range of the expected values for the different contributions we have identified, in line with similar results reported in the literature (Ref. 59 cited). In particular, the $R_{1}-Q_{1}$ network, attributed to the polycrystalline photoelectrode, with $C_{1}$ values in the order of $10^{-8} \mathrm{~F}$, should arise from the grain-boundary contribution. Observing the electrical response arising from the corresponding bulk would likely need to expand the measurements to higher frequencies (i.e., above $100 \mathrm{kHz}$ ). The values of $\mathrm{Q}_{2}$ and $\mathrm{Q}_{3}$ are also compatible in magnitude order (significantly higher than expected for grain-boundary or bulk effects) with the designated interface and diffusion contributions. The constant phase element in parallel with the resistors $\left(R_{1}, R_{2}\right.$ and $\left.R_{3}\right)$ can be converted into the capacitances $\left(C_{1}, C_{2}\right.$ and $\left.C_{3}\right)$ through the Eq. (6), 58 where $\mathrm{C}$ is the resulting capacitance, $\mathrm{Y}_{0}$ is the admittance value of the constant phase element, $\mathrm{R}$ is the resistance value and $n$ is the exponent of the constant phase element ${ }^{58}$.

$$
\mathrm{C}=\mathrm{Y}_{0}^{1 / \mathrm{n}} \times \mathrm{R}^{(1 / \mathrm{n}-1)}
$$

As expected for charge transfer $\left(\mathrm{R}_{1}\right)$ and diffusion $\left(\mathrm{R}_{3}\right)$ processes, results shown in Table 3 indicate that presence of light is responsible for an increase in conductivity. Also observed in this table, $\mathrm{R}_{2}$ is quite high under illumination, demonstrating that there is less recombination of electrons and, thus, enhanced chemical capacitance effect $\left(\mathrm{C}_{2}\right)$ at the BVO/electrolyte interface. The lifetime of the photoinjected electrons $\left(\tau_{2}\right)$ can be and was estimated using the simple expression represented by the Eq. (7). 59

$$
\tau_{2}=\mathrm{R}_{2} \times \mathrm{C}_{2}
$$

The combination of these two electrical parameters produces a very high value of lifetime $\tau_{2}$ (also presented in Table 3) for the photoinjected electrons, accounting for the high values we in fact also observed for the HC-STH efficiency (Figure S5). Furthermore, the excellent photoelectrochemical performance is the result of the exceptional electrical conductivity level of the ITO and the used active area of the photoelectrode $\sim 0.2 \mathrm{~cm}^{260}$.

Finally, the onset potential of the BVO film was also determined by processing the photocurrent data in a $\mathrm{J}^{2}$ versus applied potential plot (as shown in Figure S8), at which point the potential where the current starts to increase, that is, a reaction begins to occur, is identified. The obtained value was $0.33 \mathrm{~V}_{\mathrm{RHE}}$, much lower than the values found in bismuth- and vanadium-based films such as $\mathrm{Bi}_{46} \mathrm{~V}_{8} \mathrm{O}_{89}\left(0.53 \mathrm{~V}_{\mathrm{RHE}}\right), \mathrm{BiVO}_{4}\left(0.50 \mathrm{~V}_{\mathrm{RHE}}\right), \mathrm{BiVO}_{4} /$ $\mathrm{Bi}_{4} \mathrm{~V}_{2} \mathrm{O}_{11}\left(0.54 \mathrm{~V}_{\mathrm{RHE}}\right)$ and $\mathrm{W} / \mathrm{BiVO}_{4} / \mathrm{Bi}_{4} \mathrm{~V}_{2} \mathrm{O}_{11}\left(0.66 \mathrm{~V}_{\mathrm{RHE}}\right)^{11}$. This result confirms that the ternary heterojunction formed in our BVO film improved the charge-transfer kinetics through the photoelectrode/electrolyte interface, that is, without the use of dopants or cocatalysts.

\section{Discussion and concluding remarks}

Due to the intimate contact between $\mathrm{Bi}_{46} \mathrm{~V}_{8} \mathrm{O}_{89}$ and $\mathrm{Bi}_{3.33}\left(\mathrm{VO}_{4}\right)_{2} \mathrm{O}_{2}$ nanoplates, a sufficiently high internal polar electric field is created between both phases, resulting in the formation of a minority electron inversion layer (Fig. 8a) or minority holes (Fig. 8b) at the interface, as verified from the Mott-Schottky data (Fig. 5). The difference between the effective working functions of both semiconductors is the driving force required to achieve the electronic equilibrium through a transfer of charges between them and the creation of a spatial-charge region at the heterojunction interface. Then, charges of the same polarity are repelled from the interface, while those of the opposite polarity are attracted to it. Accordingly, when the ionic-conductor $\mathrm{Bi}_{46} \mathrm{~V}_{8} \mathrm{O}_{89}$ (with an inherent-like ability to form dipoles) is in contact with $\mathrm{Bi}_{3.33}\left(\mathrm{VO}_{4}\right)_{2} \mathrm{O}_{2}$, most of the electrons will be depleted from the interface between them, while the minority electrons (or minority holes) will be attracted to this interface, thereby 

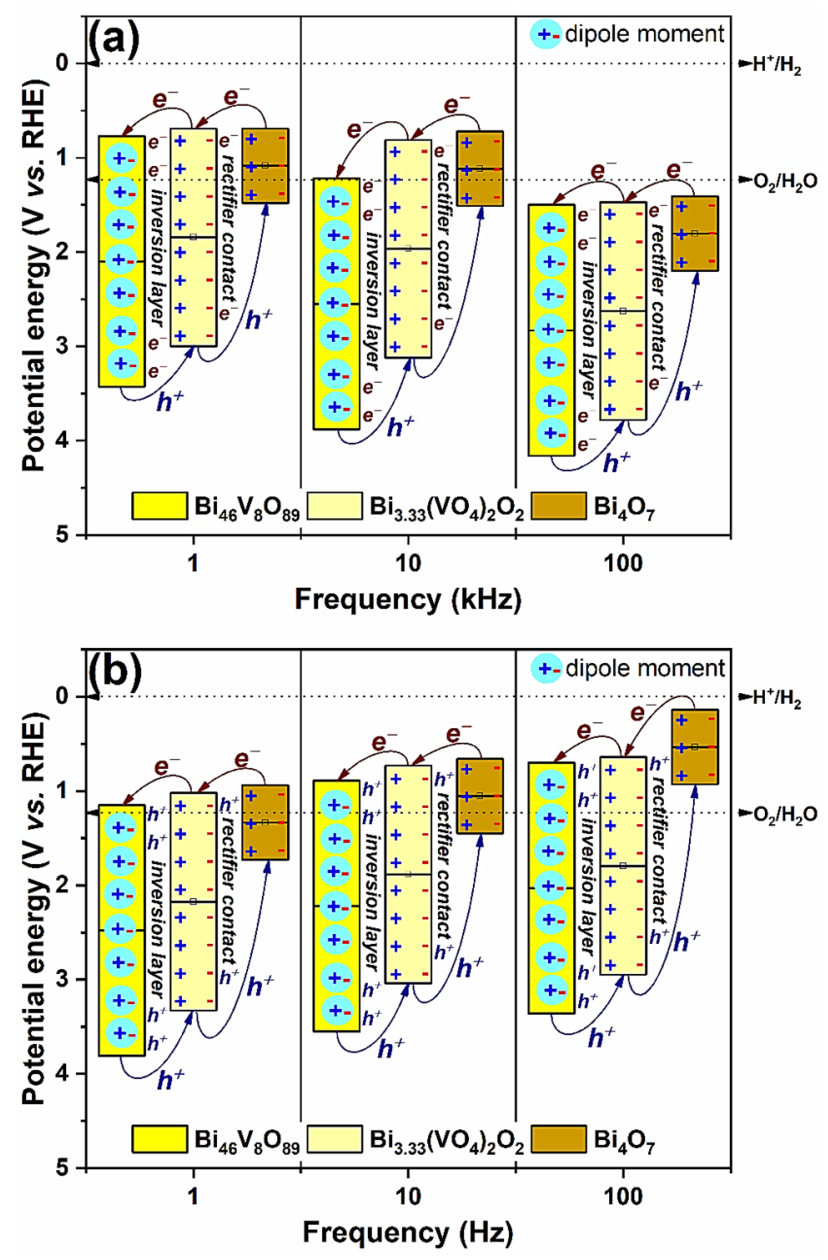

Figure 8. Schematic diagram of $\mathrm{Bi}_{4} \mathrm{O}_{7} / \mathrm{Bi}_{3.33}\left(\mathrm{VO}_{4}\right)_{2} \mathrm{O}_{2} / \mathrm{Bi}_{46} \mathrm{~V}_{8} \mathrm{O}_{89}$ heterojunction with a rectifier contact and a polarization-induced inversion layer. (a) Ternary heterojunction $p-p-p$ (virtual $n-p-n$ ), and (b) ternary heterojunction $n-n-n$ (virtual $p-n-p)$.

reversing the nature (type) of conductivity. This is in agreement with the electrochemical behavior exhibited by the Mott-Schottky data (Fig. 5), which revealed typical characteristics of $n$-type as well as $p$-type semiconductors.

With respect to the $\mathrm{Bi}_{4} \mathrm{O}_{7} / \mathrm{Bi}_{3.33}\left(\mathrm{VO}_{4}\right)_{2} \mathrm{O}_{2}$ interface, formation of a rectifier contact occurs, where the energy difference causes the transfer of electrons from $\mathrm{Bi}_{4} \mathrm{O}_{7}$ to $\mathrm{Bi}_{3.33}\left(\mathrm{VO}_{4}\right)_{2} \mathrm{O}_{2}$ in order to match the Fermi levels under open circuit conditions. Fixed charges appear at the junction interface on both sides. In $\mathrm{Bi}_{4} \mathrm{O}_{7}$, a space charge region is formed due to the positively ionized donor atoms (Figs. 8a, b). In $\mathrm{Bi}_{3.33}\left(\mathrm{VO}_{4}\right)_{2} \mathrm{O}_{2}$ there is, therefore, an accumulation of minority electrons (Fig. 8a) or minority holes (Fig. 8b) at the interface. For this junction, the electric field corresponding to the contact potential difference is directed from $\mathrm{Bi}_{4} \mathrm{O}_{7}$ to $\mathrm{Bi}_{3.33}\left(\mathrm{VO}_{4}\right)_{2} \mathrm{O}_{2}$, and its decrease, because of direct polarization, means a decrease in the potential barrier height for the electrons in $\mathrm{Bi}_{4} \mathrm{O}_{7}$; this scenario allows an easier motion of the electrons from $\mathrm{Bi}_{4} \mathrm{O}_{7}$ to $\mathrm{Bi}_{3.33}\left(\mathrm{VO}_{4}\right)_{2} \mathrm{O}_{2}$ and, therefore, an increase in the photogenerated current. This behavior is similar to that from a Schottky diode ${ }^{61,62}$.

Furthermore, as previously discussed, the easy electron injection of CB from $\mathrm{Bi}_{4} \mathrm{O}_{7}$ to $\mathrm{CB}$ from $\mathrm{Bi}_{3.33}\left(\mathrm{VO}_{4}\right)_{2} \mathrm{O}_{2}$, and later from $\mathrm{CB}$ from $\mathrm{Bi}_{3.33}\left(\mathrm{VO}_{4}\right)_{2} \mathrm{O}_{2}$ to $\mathrm{CB}$ from $\mathrm{Bi}_{46} \mathrm{~V}_{8} \mathrm{O}_{89}$ in the heterostructure, is favored because the CB and $\mathrm{VB}$ bands of $\mathrm{Bi}_{4} \mathrm{O}_{7}$ are more negative than the corresponding bands of $\mathrm{Bi}_{3.33}\left(\mathrm{VO}_{4}\right)_{2} \mathrm{O}_{2}$, and the CB and VB bands of $\mathrm{Bi}_{3.33}\left(\mathrm{VO}_{4}\right)_{2} \mathrm{O}_{2}$ are more negative than the corresponding bands of $\mathrm{Bi}_{46} \mathrm{~V}_{8} \mathrm{O}_{89}$.

In summary, due to a self-polarization-like event of the $\mathrm{Bi}_{46} \mathrm{~V}_{8} \mathrm{O}_{89}$ ionic-conductor, and depending on the applied potential and considered frequency of operation, the nature of the conductivity across this designed ternary $\mathrm{Bi}_{4} \mathrm{O}_{7} / \mathrm{Bi}_{3.33}\left(\mathrm{VO}_{4}\right)_{2} \mathrm{O}_{2} / \mathrm{Bi}_{46} \mathrm{~V}_{8} \mathrm{O}_{89}$ heterojunction can be modified, becoming either a virtually $p-n-p$ type heterojunction at low frequencies: $1-100 \mathrm{~Hz}$ (Fig. $8 \mathrm{~b}$ ), or a $n-p-n$ type heterojunction at high frequencies: $1-100 \mathrm{kHz}$ (Fig. 8a). These findings are exclusive, as they open a new design strategy to be considered for construction of multifunctional, high-efficiency hybrid photoelectrodes for sustainable artificial photosynthesis. 


\section{Experimental section}

Preparation of the precursor solution and deposition on the transparent conductive ITO-coated glass. All raw materials were used as received, without further purification. Ten millimoles of $\mathrm{Bi}_{5} \mathrm{O}(\mathrm{OH})_{9}\left(\mathrm{NO}_{3}\right)_{4}$ was dissolved in $50 \mathrm{~mL}$ of $\mathrm{CH}_{3} \mathrm{COOH}(99.7 \%)$ to get the solution "A". In another recipient, $10 \mathrm{mmol}$ of $\mathrm{NH}_{4} \mathrm{VO}_{3}$ (99\%) was dissolved in $50 \mathrm{~mL}$ of $\mathrm{NH}_{4} \mathrm{OH}(28 \%)$, producing the solution "B". Then, the solutions $\mathrm{A}$ and $\mathrm{B}$ were mixed under stirring at $80^{\circ} \mathrm{C}$ and $50 \mathrm{mmol}$ of citric acid was added to the mixture. The obtained gel was oven-dried at $150{ }^{\circ} \mathrm{C}$ for $24 \mathrm{~h}$. The precursor solution was produced by diluting the sintered powder in $\mathrm{C}_{3} \mathrm{H}_{8} \mathrm{O}_{7}(99.5 \%)$, followed by deposition on the transparent conducting ITO coated glass by applying the spin-coating method. The deposited bismuth- and vanadium-containing film, abbreviated as BVO, underwent the crystallization process in a muffle at $5{ }^{\circ} \mathrm{C} \mathrm{min}-1$ (heating rate) from room temperature to $450{ }^{\circ} \mathrm{C}$, plus annealing for $5 \mathrm{~h}$.

Characterization. The morphology of the BVO film was investigated by scanning electron microscopy (SEM, microscope model VEGA3 TESCAN) operated at $5.0 \mathrm{kV}$, coupled to an energy dispersive spectroscopy (EDS) mapping device (Oxford Instruments, Model 51-ADD0007) with $20 \mathrm{kV}$ accelerating voltage. The crystalline phases of the films were determined using an X-ray diffractometer (XRD 6,000, Shimadzu). The data were collected from 10 to $80^{\circ}$ at a step-width of $0.2^{\circ}$, scan-speed of $2.0^{\circ} \mathrm{min}^{-1}$, sampling pitch of $0.02^{\circ}$ and preset time of $5 \mathrm{~s}$, at $40 \mathrm{kV}, 30 \mathrm{~mA}$, using CuKa radiation $(\lambda=1.540560 \AA)$. Silicon was used as an external standard sample. Structure refinement through Rietveld was performed using the GSAS + EXPGUI program package ${ }^{63,64}$. Further information on the structural phases involved was extracted from Raman spectroscopy. The measurements were performed towards the 40 to $1,500 \mathrm{~cm}^{-1}$ region, using a Horiba LabRAM HR Evolution spectrometer, with a $532 \mathrm{~nm}$ laser line. The system was calibrated with a $520.7 \mathrm{~cm}^{-1}$ silicon wafer, and the LabSpec 6 software was used for data collection within a spectral resolution of $1 \mathrm{~cm}^{-1}$. The diffuse reflectance spectra (DRS) were collected within a resolution of $0.1 \mathrm{~nm}$ by using a UV-Vis spectrophotometer (UV-2501 PC Shimadzu), equipped with an ISR 240A integration sphere (and UVPC program), while $\mathrm{BaSO}_{4}$ was used as reference material (100\% transmission). The direct band-gap energies were calculated via the following Tauc equation:

$$
(\alpha h v)^{2}=\mathrm{A}\left(\mathrm{h} \nu-\mathrm{E}_{\mathrm{g}}\right)
$$

where $\mathrm{A}$ is a constant, $\mathrm{h} v$ the light energy, $\mathrm{E}_{\mathrm{g}}$ the optical band-gap energy and a refers to the absorption coefficient. The fraction of transmitted light was measured as reflectance, and the Kubelka-Munk radiative transfer model was employed to extract the a parameter. This model is described by the equation below:

$$
\mathrm{F}(\mathrm{R})=\frac{(1-\mathrm{R})^{2}}{2 \mathrm{R}}=\frac{\alpha}{\mathrm{S}}
$$

where $F(R)$ is the Kubelka-Munk function, $S$ the scattering coefficient and $R$ stands for the absolute reflectance. If the scattering coefficient is wavelength independent, then $F(R)$ is proportional to $\alpha$ and the Tauc's plots can be made using $F(R)$ instead of $\alpha^{65,66}$.

Photoelectrochemical measurements and electrochemical impedance spectroscopy. The photoelectrochemical measurements were carried out using a potentiostat AUTOLAB Potentiostat-Galvanostat PGSTAT204. The system uses a standard three-electrode cell with an $\mathrm{Ag} / \mathrm{AgCl}$ (3.0 M KCl) reference electrode, a platinum metalized FTO substrate as a counter electrode, a working electrode with irradiation area of $0.2 \mathrm{~cm}^{2}$, and a scan-rate of $20 \mathrm{mV} \mathrm{s}^{-1}$. $\mathrm{A} \mathrm{Na}_{2} \mathrm{SO}_{4}$ aqueous solution (with $0.5 \mathrm{M}$ and $\mathrm{pH}=6.6$ ) was used as electrolyte. The prepared BVO film, tested as the working electrode, was connected to a copper tape in order to measure the photoactivity. The current-potential curves were recorded in the dark and under back illumination. For converting the obtained potential vs. $\mathrm{Ag} / \mathrm{AgCl}$ to $\mathrm{RHE}$ (Reversible Hydrogen Electrode), the following expression was used:

$$
\mathrm{V}_{\mathrm{RHE}}=\mathrm{V}_{\mathrm{Ag} / \mathrm{AgCl}}+0.059 \mathrm{pH}+\mathrm{V}_{\mathrm{Ag} / \mathrm{AgCl}}^{\mathrm{o}}
$$

The $\mathrm{V}_{\mathrm{Ag} / \mathrm{AgCl}}^{\mathrm{o}}(\mathrm{KCl} 3 \mathrm{M})=0.197$ at $25^{\circ} \mathrm{C}$.

When the BVO photoelectrode behaved like a photoanode, the applied-bias-compensated half-cell solar-tohydrogen (HC-STH) efficiency was calculated from the following equation:

$$
\mathrm{HC}-\mathrm{STH}=\frac{\left|\mathrm{J}_{\text {light }}-\mathrm{J}_{\text {dark }}\right| \times\left(\mathrm{V}_{\mathrm{O}_{2} / \mathrm{H}_{2} \mathrm{O}}-\mathrm{V}_{\mathrm{RHE}}\right) \times \eta}{\mathrm{P}_{\text {light }}}
$$

On the other hand, when the BVO photoelectrode behaved like a photocathode, the equation below was used:

$$
\mathrm{HC}-\mathrm{STH}=\frac{\left|\mathrm{J}_{\text {light }}-\mathrm{J}_{\text {dark }}\right| \times\left(\mathrm{V}_{\mathrm{RHE}}-\mathrm{V}_{\mathrm{H}^{+} / \mathrm{H}_{2}}\right) \times \eta}{\mathrm{P}_{\text {light }}}
$$

where $\mathrm{V}_{\mathrm{RHE}}$ is the applied potential, $\mathrm{J}_{\mathrm{dark}}$ and $\mathrm{J}_{\text {light }}$ are the photocurrent densities in the dark and under irradiated light, respectively, $\mathrm{P}_{\text {light }}$ is the power density of the irradiated light, while $\mathrm{V}_{\mathrm{O} 2 / \mathrm{H} 2 \mathrm{O}}$ and $\mathrm{V}_{\mathrm{H}}{ }^{+} / \mathrm{H} 2$ represent the equilibrium potentials of oxygen $\left(+1.23 \mathrm{~V}_{\mathrm{RHE}}\right)$ and hydrogen $\left(0 \mathrm{~V}_{\mathrm{RHE}}\right)$ evolution, respectively. Finally, the faraday efficiency is symbolized by $\eta^{67-69}$. 
The electrochemical impedance spectroscopy was performed using the AUTOLAB Potentiostat-Galvanostat PGSTAT204 equipped with the FRA32M module. The standard three-electrode cell configuration was also used, together with the $\mathrm{Na}_{2} \mathrm{SO}_{4}$ aqueous solution $(0.5 \mathrm{M})$ as electrolyte. The impedance measurements were carried out under $\mathrm{a}+1.23 \mathrm{~V}_{\mathrm{RHE}} \mathrm{DC}$ potential bias, with an amplitude of $0.01 \mathrm{~V}_{\mathrm{RMS}}$, where RMS is the root mean square, in the frequency range of $100 \mathrm{mHz}$ to $100 \mathrm{kHz}$. An Xe Lamp $\left(\lambda>450 \mathrm{~nm}, 100 \mathrm{~mW} \mathrm{~cm}^{-2}\right)$ was used as the light source. The measured data were processed using Nyquist plots and fitted using the NOVA 2.1.3 software (Metrohm Autolab BV, Netherlands).

It was used as a source of light a $300 \mathrm{~W}$ Xenon arc lamp (Newport Ozone Free Model 6,258). The equipment used to measure the intensity (power density) of the irradiated light was a Newport model 1916-R optical power meter equipped with an UV sensor (Newport UV 818-UV/DB). An AM 1.5 filter in front of the light output was also used as the sun simulator.

Mott-Schottky data acquisition. The spectra were collected using also the AUTOLAB PotentiostatGalvanostat PGSTAT204 equipped with the FRA32M module, and a cell configuration with three electrodes: a reference electrode of $\mathrm{Ag} / \mathrm{AgCl}(3.0 \mathrm{M} \mathrm{KCl})$, a platinum metalized FTO substrate as counter electrode wire and a working electrode (the BVO film) with $0.2 \mathrm{~cm}^{2}$ area in the dark, applying a potential from -0.7 to $+0.7 \mathrm{~V}_{\mathrm{Ag} / \mathrm{AgCl}}$ in the frequency range of $1 \mathrm{~Hz}$ to $100 \mathrm{kHz}$, using a step of $0.03 \mathrm{~V}_{\mathrm{Ag} / \mathrm{AgCl}}$ and amplitude of $0.01 \mathrm{~V}_{\mathrm{RMS}}$. The measured spectra were fitted using the NOVA 2.1.3 software (Metrohm Autolab BV, Netherlands). Again, the $\mathrm{Na}_{2} \mathrm{SO}_{4}$ solution $(0.5 \mathrm{M})$ was used as electrolyte for these electrochemical measurements.

Received: 27 March 2020; Accepted: 11 June 2020

Published online: 30 June 2020

\section{References}

1. Duan, L., Tong, L., Xu, Y. \& Sun, L. Visible light-driven water oxidation-from molecular catalysts to photoelectrochemical cells. Energy Environ. Sci. 4, 3296-3313 (2011).

2. Gratzel, M. Photoelectrochemical cells. Nature 414, 338-344 (2001).

3. Liu, Q. et al. A multijunction of $\mathrm{ZnIn}_{2} \mathrm{~S}_{4}$ nanosheet/ $\mathrm{TiO}_{2}$ film/Si nanowire for significant performance enhancement of water splitting. Nano Res. 8, 3524-3534 (2015).

4. Swierk, J. R. \& Mallouk, T. E. Design and development of photoanodes for water-splitting dye-sensitized photoelectrochemical cells. Chem. Soc. Rev. 42, 2357-2387 (2013)

5. Walter, M. G. et al. Solar water splitting cells. Chem. Rev. 110, 6446-6473 (2010).

6. Li, J. \& Wu, N. Semiconductor-based photocatalysts and photoelectrochemical cells for solar fuel generation: a review. Catal. Sci. Technol. 5, 1360-1384 (2015).

7. Li, Z., Luo, W., Zhang, M., Feng, J. \& Zou, Z. Photoelectrochemical cells for solar hydrogen production: current state of promising photoelectrodes, methods to improve their properties, and outlook. Energy Environ. Sci. 6, 347-370 (2013).

8. Kim, T. L., Choi, M.-J. \& Jang, H. W. Boosting interfacial charge transfer for efficient water-splitting photoelectrodes: progress in bismuth vanadate photoanodes using various strategies. MRS Commun. 8, 809-822 (2018).

9. Peerakiatkhajohn, P., Yun, J.-H., Wang, S. \& Wang, L. Review of recent progress in unassisted photoelectrochemical water splitting: from material modification to configuration design. J. Photon. Energy 7, 012006 (2016).

10. dos Santos, W. S. et al. Photoelectrochemical water oxidation over fibrous and sponge-like $\mathrm{BiVO}_{4} / \beta-\mathrm{Bi}_{4} \mathrm{~V}_{2} \mathrm{O}_{11}$ photoanodes fabricated by spray pyrolysis. Appl. Catal. B Environ. 182, 247-256 (2016).

11. dos Santos, W. S. et al. A hole inversion layer at the $\mathrm{BiVO}_{4} / \mathrm{Bi}_{4} \mathrm{~V}_{2} \mathrm{O}_{11}$ interface produces a high tunable photovoltage for water splitting. Sci. Rep. 6, 31406 (2016).

12. dos Santos, W. S. et al. Bismuth vanadate photoelectrodes with high photovoltage as photoanode and photocathode in photoelectrochemical cells for water splitting. Chemsuschem 11, 589-597 (2018).

13. Lopes, O. F., Carvalho, K. T. G., Avansi, W. \& Ribeiro, C. Growth of $\mathrm{BiVO}_{4}$ nanoparticles on a $\mathrm{Bi}_{2} \mathrm{O}_{3}$ surface: effect of heterojunction formation on visible irradiation-driven catalytic performance. J. Phys. Chem. C 121, 13747-13756 (2017).

14. Lv, C., Chen, G., Sun, J. \& Zhou, Y. Construction of $\alpha-\beta$ phase junction on $\mathrm{Bi}_{4} \mathrm{~V}_{2} \mathrm{O}_{11}$ via electrospinning retardation effect and its promoted photocatalytic performance. Inorg. Chem. 55, 4782-4789 (2016).

15. Liu, Z., Niu, J., Feng, P., Sui, Y. \& Zhu, Y. One-pot synthesis of $\mathrm{Bi}_{24} \mathrm{O}_{31} \mathrm{Br}_{1} 0 / \mathrm{B}_{\mathrm{i}} 4_{\mathrm{V}} 2_{\mathrm{O} 1} 1$ heterostructures and their photocatalytic properties. RSC Adv. 4, 43399-43405 (2014).

16. Lv, T. et al. Facile synthesis of $\mathrm{CdS} / \mathrm{Bi}_{4} \mathrm{~V}_{2} \mathrm{O}_{11}$ photocatalysts with enhanced visible-light photocatalytic activity for degradation of organic pollutants in water. Dalton Trans. 46, 12675-12682 (2017).

17. Liu, T., Mao, Y. G. \& Peng, Y. Synthesis of $\mathrm{Bi}_{2} \mathrm{O}_{3}-\mathrm{Bi}_{4} \mathrm{~V}_{2} \mathrm{O}_{11}$ heterojunctions with high interface quality for enhanced visible light photocatalysis in degradation of high-concentration phenol and MO dyes. CrystEngComm 20, 2553-2561 (2018).

18. Cong, Y. et al. Enhanced Photoelectrocatalytic Activity Of A Novel $\mathrm{Bi}_{2} \mathrm{O}_{3}-\mathrm{BiPO}_{4}$ composite electrode for the degradation of refractory pollutants under visible light irradiation. Ind. Eng. Chem. Res. 55, 1221-1228 (2016).

19. Kalanur, S. S., Yoo, I.-H., Park, J. \& Seo, H. Insights into the electronic bands of $\mathrm{WO}_{3} / \mathrm{BiVO}_{4} / \mathrm{TiO}_{2}$, revealing high solar water splitting efficiency. J. Mater. Chem. A 5, 1455-1461 (2017).

20. Zhu, M. et al. Boosting the visible-light photoactivity of $\mathrm{BiOCl} / \mathrm{BiVO}_{4} / \mathrm{N}-\mathrm{GQD}$ ternary heterojunctions based on internal Z-scheme charge transfer of N-GQDs: simultaneous band gap narrowing and carrier lifetime prolonging. ACS Appl. Mater. Interfaces $\mathbf{9}$, 38832-38841 (2017).

21. Hwang, S. W. et al. Solution-processed $\mathrm{TiO}_{2} / \mathrm{BiVO}_{4} / \mathrm{SnO}_{2}$ triple-layer photoanode with enhanced photoelectrochemical performance. J. Alloys Compd. 785, 1245-1252 (2019).

22. McKone, J. R., Lewis, N. S. \& Gray, H. B. Will solar-driven water-splitting devices see the light of day?. Chem. Mater. 26, 407-414 (2014).

23. Prévot, M. S. \& Sivula, K. Photoelectrochemical tandem cells for solar water splitting. J. Phys. Chem. C 117, 17879-17893 (2013).

24. Zhang, K., Ma, M., Li, P., Wang, D. H. \& Park, J. H. Water splitting progress in tandem devices: moving photolysis beyond electrolysis. Adv. Energy Mater. 6, 1600602 (2016).

25. Grätzel, M. Photochemical methods for the conversion of light into chemical energy. Ber. Bunsen-Ges. Phys. Chem. 84, 981-991 (1980).

26. Darriet, J., Launay, J. C. \& Zúniga, F. J. Crystal structures of the ionic conductors $\mathrm{Bi}_{46} \mathrm{M}_{8} \mathrm{O}_{89}(\mathrm{M}=\mathrm{P}, \mathrm{V})$ related to the fluorite-type structure. J. Solid State Chem. 178, 1753-1764 (2005).

27. Kuang, X., Payne, J. L., Farrell, J. D., Johnson, M. R. \& Evans, I. R. Polymorphism and oxide ion migration pathways in fluorite-type bismuth vanadate, $\mathrm{Bi}_{46} \mathrm{~V}_{8} \mathrm{O}_{89}$. Chem. Mater. 24, 2162-2167 (2012), 
28. Kumada, N. et al. Preparation and crystal structure of a new bismuth vanadate, $\mathrm{Bi}_{3.33}\left(\mathrm{VO}_{4}\right)_{2} \mathrm{O}_{2}$. Mater. Res. Bull. 46, 962-965 (2011).

29. Guan, H. \& Feng, Y. Facile synthesis and purplish blue luminescence of the binary mixed valence compound $\mathrm{Bi}_{4} \mathrm{O}_{7}$ microcrystals. Mater. Lett. 143, 269-272 (2015).

30. Sun, M. et al. Fabrication of a novel Z-scheme $\mathrm{g}-\mathrm{C}_{3} \mathrm{~N}_{4} / \mathrm{Bi}_{4} \mathrm{O}_{7}$ heterojunction photocatalyst with enhanced visible light-driven activity toward organic pollutants. J. Colloid Interface Sci. 501, 123-132 (2017).

31. Dinnebier, R. E., Ibberson, R. M., Ehrenberg, H. \& Jansen, M. The crystal structures of the binary mixed valence compound $\mathrm{Bi}_{3}{ }^{(I I I)} \mathrm{Bi}^{(\mathrm{V})} \mathrm{O}_{7}$ and isotypic $\mathrm{Bi}_{3} \mathrm{SbO}_{7}$ as determined by high resolution X-ray and neutron powder diffraction. J. Solid State Chem. 163, 332-339 (2002).

32. Buixaderas, E. et al. Compositional behavior of Raman-active phonons in $\mathrm{Pb}\left(\mathrm{Zr}_{1-\mathrm{x}} \mathrm{Ti}_{\mathrm{x}}\right) \mathrm{O}_{3}$ ceramics. Phys. Rev. B 91, 014104 (2015).

33. Đorđević, T. \& Karanović, L. A new anion-deficient fluorite-related superstructure of $\mathrm{Bi}_{28} \mathrm{~V}_{8} \mathrm{O}_{62}$. J. Solid State Chem. 220, 259-269 (2014).

34. Zhang, G., Cai, L., Zhang, Y. \& Wei, $\mathrm{Y} \mathrm{Bi}^{5+}, \mathrm{Bi}^{(3-x)+}$, and oxygen vacancy induced $\mathrm{BiOCl}_{\mathrm{x}} \mathrm{I}_{1-\mathrm{x}}$ solid solution toward promoting visible-light driven photocatalytic activity. Chem. Eur. J. 24, 7434-7444 (2018).

35. Hardcastle, F. D., Wachs, I. E., Eckert, H. \& Jefferson, D. A. Vanadium(V) environments in bismuth vanadates: a structural investigation using Raman spectroscopy and solid state ${ }^{51}$ V NMR. J. Solid State Chem. 90, 194-210 (1991).

36. Hardcastle, F. D. \& Wachs, I. E. Determination of vanadium-oxygen bond distances and bond orders by Raman spectroscopy. J. Phys. Chem. 95, 5031-5041 (1991).

37. Shvets, P., Dikaya, O., Maksimova, K. \& Goikhman, A. A review of Raman spectroscopy of vanadium oxides. J. Raman Spectrosc. 50, 1226-1244 (2019).

38. Hu, Y. et al. Temperature-induced phase changes in bismuth oxides and efficient photodegradation of phenol and p-chlorophenol. J. Hazard. Mater. 301, 362-370 (2016).

39. Jia, Y. et al. Oxygen vacancy rich $\mathrm{Bi}_{2} \mathrm{O}_{4}-\mathrm{Bi}_{4} \mathrm{O}_{7}-\mathrm{BiO}_{2-\mathrm{x}}$ composites for UV-vis-NIR activated high efficient photocatalytic degradation of bisphenol A. J. Hazard. Mater. 382, 121121 (2020).

40. Watanabe, A. Preparation and characterization of a new triclinic compound $\mathrm{Bi}_{3.5} \mathrm{~V}_{1.2} \mathrm{O}_{8.25}$ to show the known phase $\mathrm{Bi}_{4} \mathrm{~V}_{2} \mathrm{O}_{11}$ to be nonexistent as a single phase. J. Solid State Chem. 161, 410-415 (2001).

41. Awasthi, R. R. \& Das, B. Structural transition and tunable optical, morphological and magnetic properties of $\mathrm{Mn}$-doped $\mathrm{BiFeO}_{3}$ films. Optik 194, 162973 (2019).

42. Thanikaikarasan, S., Karthickprabhu, S., Dhanasekaran, D. \& Vijayan, V. Physical, chemical and optical properties of CdSe and CdSe: $\mathrm{Zn}$ thin films obtained through low cost electrochemical route. Mater. Today: Proc. 21, 73-77 (2019).

43. Ganguly, P. \& Hegde, M. S. Evidence for double valence fluctuation in metallic oxides of lead. Phys. Rev. B 37, 5107-5112 (1988).

44. Sajjad, S., Leghari, S. A. K. \& Zhang, J. Nonstoichiometric $\mathrm{Bi}_{2} \mathrm{O}_{3}$ : efficient visible light photocatalyst. RSC Adv. 3, 1363-1367 (2013).

45. Rakesh, K. et al. Role of doping-induced photochemical and microstructural properties in the photocatalytic activity of $\mathrm{InVO}_{4}$ for splitting of water. J. Mater. Sci. 46, 5466-5476 (2011).

46. Gelderman, K., Lee, L. \& Donne, S. W. Flat-band potential of a semiconductor: using the Mott-Schottky equation. J. Chem. Educ. 84, 685-688 (2007).

47. Lee, K. J., Elgrishi, N., Kandemir, B. \& Dempsey, J. L. Electrochemical and spectroscopic methods for evaluating molecular electrocatalysts. Nat. Rev. Chem. 1, 0039 (2017).

48. Xie, Y., Ju, Y., Toku, Y. \& Morita, Y. Fabrication of $\mathrm{Fe}_{2} \mathrm{O}_{3}$ nanowire arrays based on oxidation-assisted stress-induced atomicdiffusion and their photovoltaic properties for solar water splitting. RSC Adv. 7, 30548-30553 (2017).

49. Oliveira, A. T. et al. High water oxidation performance of W-doped $\mathrm{BiVO}_{4}$ photoanodes coupled to $\mathrm{V}_{2} \mathrm{O}_{5}$ rods as a photoabsorber and hole carrier. Sol. RRL 2, 1800089 (2018).

50. Xu, W. \& Scott, K. The effects of ionomer content on PEM water electrolyser membrane electrode assembly performance. Int. J. Hydrog. Energy 35, 12029-12037 (2010).

51. Zhou, H. et al. Water splitting by electrolysis at high current densities under 1.6 volts. Energy Environ. Sci. 11, 2858-2864 (2018).

52. Anantharaj, S. et al. Precision and correctness in the evaluation of electrocatalytic water splitting: revisiting activity parameters with a critical assessment. Energy Environ. Sci. 11, 744-771 (2018).

53. Li, J., Guo, L., Zhou, J., Song, Q. \& Liang, Z. Enhancing the photoelectrochemical performance of $\mathrm{BiVO}_{4}$ by decorating only its (040) facet with self-assembled Ag@AgCl QDs. J. Solid State Electrochem. 22, 2425-2434 (2018).

54. Kakaei, K., Esrafili, M. D. \& Ehsani, A. In Interface Science and Technology, Vol. 27 (eds Kakaei, K. et al.) 303-337 (Elsevier, New York, 2019).

55. Surendranath, Y., Bediako, D. K. \& Nocera, D. G. Interplay of oxygen-evolution kinetics and photovoltaic power curves on the construction of artificial leaves. PNAS USA 109, 15617-15621 (2012).

56. Holze, R., Elektrochemie, C. H. \& Hamann, W. Vielstich Wiley-VCH Verlagsgesellschaft mbH, Weinheim 1998, 602 S., 301 Abb., 35 Tab., brosch., DM 98, ISBN 3-527-27894-X. Chem. Ing. Tech. 71, 1208-1209 (1999).

57. Zhong, S., Xi, Y., Chen, Q., Chen, J. \& Bai, S. Bridge engineering in photocatalysis and photoelectrocatalysis. Nanoscale 12, 5764-5791 (2020).

58. Orazem, M. E. \& Tribollet, B. Time-Constant Dispersion. In: Electrochemical Impedance Spectroscopy (ed John Wiley \& Sons) Ch. $13,233-263$ (2008).

59. Kundu, A., Shit, A. \& Nandi, S. Carbon dot assisted synthesis of nanostructured polyaniline for dye sensitized solar cells. Energy Fuels 31, 7364-7371 (2017).

60. Lee, Y. W. et al. Unbiased biocatalytic solar-to-chemical conversion by $\mathrm{FeOOH} / \mathrm{BiVO}_{4} /$ perovskite tandem structure. Nat. Commun. 9, 4208 (2018).

61. Léonard, F. \& Tersoff, J. Role of fermi-level pinning in nanotube schottky diodes. Phys. Rev. Lett. 84, 4693-4696 (2000).

62. Lin, F. \& Boettcher, S. W. Adaptive semiconductor/electrocatalyst junctions in water-splitting photoanodes. Nat. Mater. 13, 81-86 (2013).

63. Larson, A. C. \& Dreele, R. B. V. General structural analysis system (GSAS). Los Alamos National Laboratory Report LAUR, 86-748 (2004).

64. Toby, B. EXPGUI, a graphical user interface for GSAS. J. Appl. Crystallogr. 34, 210-213 (2001).

65. Barton, D. G., Shtein, M., Wilson, R. D., Soled, S. L. \& Iglesia, E. Structure and electronic properties of solid acids based on tungsten oxide nanostructures. J. Phys. Chem. B 103, 630-640 (1999).

66. Finlayson, A. P., Tsaneva, V. N., Lyons, L., Clark, M. \& Glowacki, B. A. Evaluation of Bi-W-oxides for visible light photocatalysis. Phys. Status Solidi A 203, 327-335 (2006).

67. Dotan, H., Mathews, N., Hisatomi, T., Grätzel, M. \& Rothschild, A. On the solar to hydrogen conversion efficiency of photoelectrodes for water splitting. J. Phys. Chem. Lett. 5, 3330-3334 (2014).

68. Hisatomi, T., Kubota, J. \& Domen, K. Recent advances in semiconductors for photocatalytic and photoelectrochemical water splitting. Chem. Soc. Rev. 43, 7520-7535 (2014).

69. Pei, L., Xu, Z., Yan, S. \& Zou, Z. Temperature-controlled evolution of microstructures that promote charge separation in a TaON photoanode for enhanced solar energy conversion. J. Mater. Chem. A 5, 12848-12855 (2017). 


\title{
Acknowledgements
}

The authors would like to thank the financial support from the National Council of Scientific and Technological Development (CNPq) under Grant 303314/2016-8, Minas Gerais Research Foundation (FAPEMIG) under grants PPM-00661-16 and APQ-02875-18, Coordenação de Aperfeiçoamento de Pessoal de Nível Superior-Brasil (CAPES)-Finance Code 001, and São Paulo Research Foundation (FAPESP) under Grant 2007/54974-5, from Brazil, and ONR (N000141613096) and NSF (01002380) from the USA. We also thank the Photochemistry and Material Sciences, Photochemistry and Lignocellulosic Materials and Multiusers laboratories (from the Institute of Chemistry at the Federal University of Uberlândia) for the experimental facilities.

\section{Author contributions}

J.D.S.G. supervised the project and led the discussions and full analyses of the results. W.S.S. wrote the manuscript, planned, performed and interpreted the results. E.J.C. participated in the synthesis of the films and data collection. Y.M.-G. performed the XRD and Raman spectroscopy and participated in the discussion of such results. L.L.N. collected the electrochemical measurements and A.O.T.P. interpreted the electrochemical measurements. R.G. participated in the interpretation of the Mott-Schottky analysis and A.S.B. interpreted the impedance spectroscopy results. J.-C.M'P. also participated in the discussions and full analyses of the results. All the authors were involved in the discussions of the results and commented on the manuscript.

\section{Competing interests}

The authors declare no competing interest.

\section{Additional information}

Supplementary information is available for this paper at https://doi.org/10.1038/s41598-020-67768-y.

Correspondence and requests for materials should be addressed to J.D.S.G.

Reprints and permissions information is available at www.nature.com/reprints.

Publisher's note Springer Nature remains neutral with regard to jurisdictional claims in published maps and institutional affiliations.

\begin{abstract}
(c) (i) Open Access This article is licensed under a Creative Commons Attribution 4.0 International License, which permits use, sharing, adaptation, distribution and reproduction in any medium or format, as long as you give appropriate credit to the original author(s) and the source, provide a link to the Creative Commons license, and indicate if changes were made. The images or other third party material in this article are included in the article's Creative Commons license, unless indicated otherwise in a credit line to the material. If material is not included in the article's Creative Commons license and your intended use is not permitted by statutory regulation or exceeds the permitted use, you will need to obtain permission directly from the copyright holder. To view a copy of this license, visit http://creativecommons.org/licenses/by/4.0/.
\end{abstract}

(C) The Author(s) 2020 